\title{
Protected Cropping in Warm Climates: A Review of Humidity Control and Cooling Methods
}

\author{
Barkat Rabbi ${ }^{1}$, Zhong-Hua Chen ${ }^{1,2}$ and Subbu Sethuvenkatraman ${ }^{3, *}$ \\ 1 School of Science and Health, Western Sydney University, Penrith, NSW 2751, Australia \\ 2 Hawkesbury Institute for the Environment, Western Sydney University, Penrith, NSW 2751, Australia \\ 3 Energy Centre, Commonwealth Scientific and Industrial Research Organisation (CSIRO), 10 Murray Dwyer \\ Circuit, Mayfield West 2304, Australia \\ * Correspondence: subbu.sethuvenkatraman@csiro.au
}

Received: 3 June 2019; Accepted: 16 July 2019; Published: 17 July 2019

\begin{abstract}
The projected increase of the world's population, coupled with the shrinking area of arable land required to meet future food demands, is building pressure on Earth's finite agricultural resources. As an alternative to conventional farming methods, crops can be grown in protected environments, such as traditional greenhouses or the more modern plant factories. These are usually more productive and use resources more efficiently than conventional farming and are now receiving much attention-especially in urban and peri-urban areas. Traditionally, protected cropping has been predominantly practised in temperate climates, but interest is rapidly rising in hot, arid areas and humid, tropical regions. However, maintaining suitable climatic conditions inside protected cropping structures in warm climates-where warm is defined as equivalent to climatic conditions that require cooling - is challenging and requires different approaches from those used in temperate conditions. In this paper, we review the benefits of protected cropping in warm climates, as well as the technologies available for maintaining a controlled growing environment in these regions. In addition to providing a summary of active cooling methods, this study summarises photovoltaic (PV)-based shading methods used for passive cooling of greenhouses. Additionally, we also summarise the current humidity-control techniques used in the protected cropping industry and identify future research opportunities in this area. The review includes a list of optimum growing conditions for a range of crop species suited to protected cropping in warm climates.
\end{abstract}

Keywords: greenhouse horticulture; plant factories; climate-control systems; cooling technology; humidity control; energy use

\section{Introduction}

Over the past 20 years, the concept of maximising a sustainable yield per unit area has been the primary goal of agriculture and horticulture industries, due to population growth, climate change, water shortage, declining arable land and biotic and abiotic stresses to crops [1-3]. More than two-thirds of the world's population will be urbanised by 2050 [4], while the available arable land is projected to decrease by one-third [2]. The arable land per capita of the global population has already decreased from 0.37 ha in 1961 to 0.19 ha in 2015 (Table S1), with similar trends seen in individual countries [2]. Consequently, farmers are under pressure to increase productivity and look for alternative cropping techniques that are both energy efficient and environmentally sustainable in the long run $[5,6]$. Suitable solutions include protected cropping (or controlled growing) systems, which can be broadly classified into two categories from the climate-control perspective: greenhouses and plant factories [7-10].

A greenhouse, also known as a glasshouse, is an enclosed environment that generates its own microclimate. This enables farmers to manipulate inputs and outputs by controlling parameters such as 
heating, cooling, temperature, humidity, $\mathrm{CO}_{2}$ enrichment and fertigation (applying liquid fertiliser via irrigation). The result is an environment that is conducive for plant growth and development $[11,12]$. This cropping typology is semi-controlled and mostly relies on solar energy for crop photosynthesis and heating. Compared with field-grown crops, a greenhouse produces 5-10 times higher yields per unit area (Table S2) [13] and has 5-10 times higher water-use efficiency [14]. Fully closed or semi-closed greenhouses use both solar and artificial illumination to reduce energy consumption [15]. A closed greenhouse can also improve production rate, water conservation and sustainable management [16]. For example, Vadiee et al. [17] showed a $>50 \%$ energy reduction potential for a closed greenhouse operating in Nordic climatic conditions. However, reports on closed greenhouses in warm climates are few.

Plant factories, or indoor farms, are fully enclosed, tightly controlled systems that use $100 \%$ artificial lighting. They are designed for optimising crop production while retaining resources, such as water and $\mathrm{CO}_{2}$, and are thus gaining popularity in highly populated countries, including Japan, Korea and Taiwan [18]. Although plant factories do significantly improve water-use efficiency and yield of vegetable production [15], they make no use of abundant solar energy especially in warm climates.

The energy used for climate control in both systems can be a significant component of their running cost, and is dependent on factors such as cooling, heating, moisture control, crop type and variety, physical location and climate. For instance, heating, cooling and dehumidification in lettuce-production greenhouses accounted for an estimated $30 \%-40 \%$ of energy use per cultivation area $\left(\mathrm{MJ} / \mathrm{m}^{2}\right)$, although this depended on climatic conditions [15]. While heating technologies for protective cropping in temperate regions have been extensively studied e.g., [12,19-21], climate-control approaches for warm regions are limited [22-25]. Protected cropping industries primarily began in highly populated temperate regions with low temperatures and limited winter sunlight. However, due to the growing global population and the decline in available arable land, research interest in protected cropping in warm and arid regions has recently increased.

This review aims to identify climate-control solutions available for protected cropping in regions that predominantly require cooling methods combined with humidification or dehumidification. The existing literature lacks enough comprehensive justification for protected cropping in warm climatic conditions. We address this gap by analysing the benefits of controlled crop cultivation in warm regions and information on the climate-control requirements with specific emphasis on humidity-control methods. Findings from our review of both greenhouse climate control and the recently growing area of plant factory systems are then discussed.

\section{Benefits of Protected Cropping in Warm Climates}

Warm climates have higher solar radiation than temperate zones. If the water resource is not a constraint, open field cropping can therefore be practised year-round in warm regions. Consequently, protected cropping has not been given much consideration in the past. However, a combination of factors, such as food security, a need to reduce carbon footprints, and growing interest in locally produced, fresh produce has now prompted governments and farmers in warm and arid climatic zones to consider protected cropping $[26,27]$. This is particularly important in warmer climates characterised by erratic rainfall coupled with higher-than-usual water evaporation $[28,29]$.

As protected cropping allows the control and manipulation of microclimate, thereby creating a conducive environment for plant health and growth, it could deliver economic, environmental, and social benefits (Figure 1). Each of these is discussed further below. 

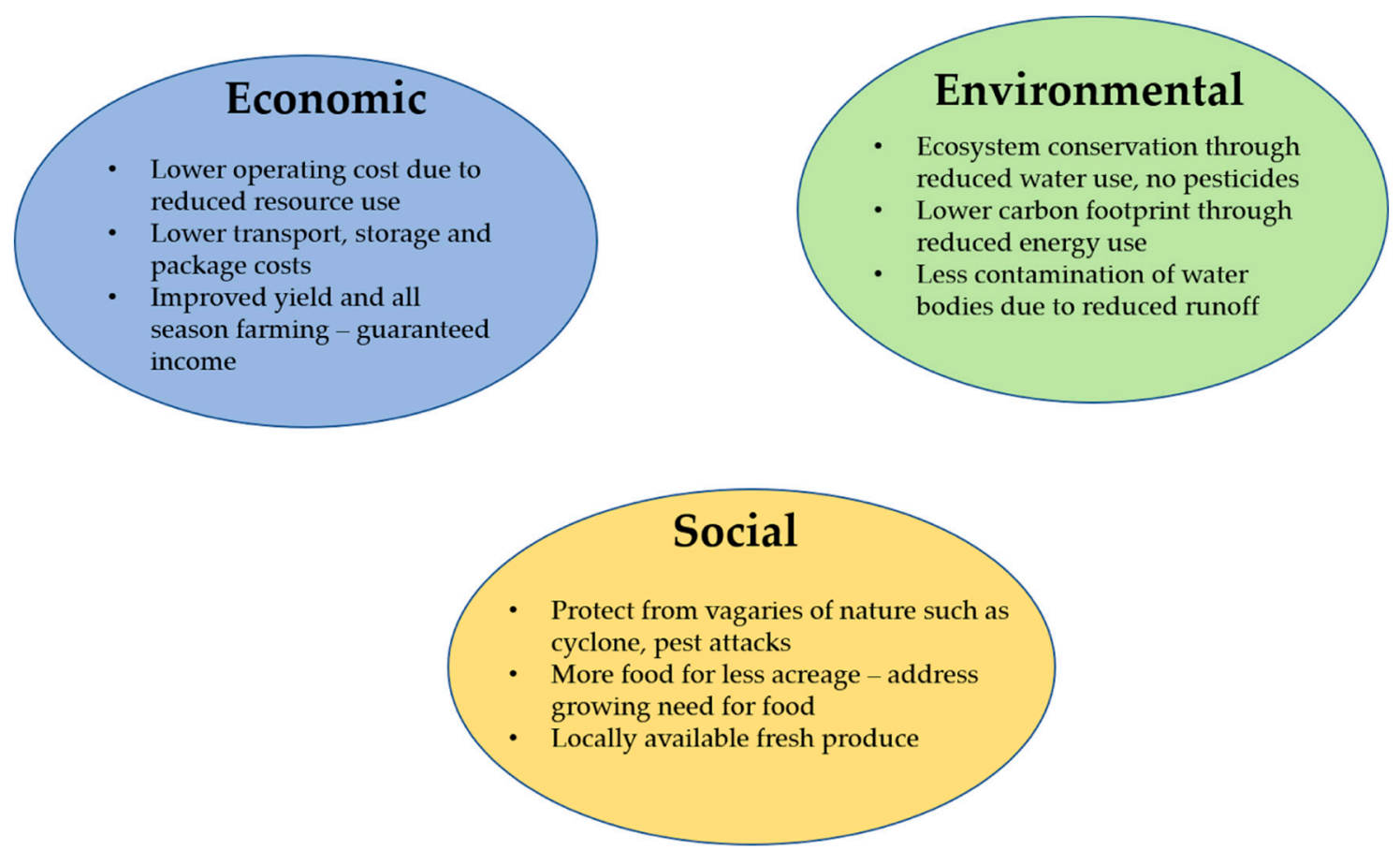

Figure 1. Potential economic, environmental and social benefits of protected cropping in warm climates.

\subsection{Economic Benefits}

The economic advantages of protected cropping are savings on transportation fuel, storage and refrigeration [30] and management of pests and weeds [31]. Some of the most profitable leafy vegetables, such as lettuce (Lactuca sativa L.), perform well in climate-controlled conditions, providing profitable return to growers in all seasons [31]. Yield components are also higher in protected cropping than field farming, which can be translated into higher profits [31,32]. A recent study showed that lettuces grown in vertical systems produce 13.8 times more fresh weight $\left(\mathrm{kg} / \mathrm{m}^{2}\right)$ per unit floor area than those grown in the field. [33].

\subsection{Environmental Benefits}

Protected cropping enables urban dwellers to grow crops in soil-free substrates using fertigation, which benefits the environment by preventing fertiliser runoffs contaminating the natural and pristine ecosystems [31,34]. It also conserves our precious water resources, with plant factories shown to reduce water consumption by up to $97 \%$ compared to conventional farming [30,32]. The need for toxic pesticides and herbicides is also reduced. These chemicals are not only dangerous to human wellbeing, but also a threat to entire biomes and ecosystems [34,35]. Furthermore, protected cropping decreases food miles and greenhouse gas emissions generated by long-distance transportation, cooling, storage and packaging [36]. It may also minimise fossil-fuel dependency by using wind, solar and geothermal energy [30,37,38].

\subsection{Social Benefits}

One of the key social advantages of protected cropping is the creation of local employment for urban dwellers [39]. For instance, Orsini et al. [40] reported that urban and peri-urban farming in its various forms (e.g., greenhouse horticulture, plant factories) would provide jobs for marginalised social classes, including women and minority groups. In addition, given the proximity of residences and schools to protected cropping premises, parents with school-age children will be able to combine paid jobs with unpaid home duties [37,41,42]. Moreover, price of the produce for urban dwellers will be comparable to traditional farming, given that there is much less fuel, transportation and 
middleman involvement which usually accounts for $60 \%$ of product prices [34]. Similar studies have shown that engaging low socioeconomic populations in protected cropping leads to better health, food security and education [37,41-43]. Advanced greenhouses and plant factories also offer employment opportunities for engineers, architects, plumbers, electricians, agricultural scientists, growers, agronomists, horticulturists, economists and marketers.

Another social benefit of protected cropping is the educational aspect, which can give young and adult citizens lifelong, hands-on skills that may ultimately boost their overall environmental awareness and help them make informed choices about healthy food habits [37]. Protected cropping premises could also play an important role in research and development, as well as providing training and education for the next generation of skilled employees in the horticultural industry.

\section{Climate-Control Requirements for Horticultural Crops in Warm Climates}

To grow healthy, productive plants in protected cropping conditions, temperature (air and soil), humidity, light (Photosynthetically Active Radiation: PAR), $\mathrm{CO}_{2}$, nutrition, electrical conductivity (EC) and $\mathrm{pH}$ need to be controlled [44]. Of these variables, temperature, humidity and light are the vital determinants of the microclimate inside greenhouses and plant factories [45].

\subsection{Temperature}

Temperature is the premier environmental factor that influences all stages of plant growth cycles, such as germination, vegetative growth, flowering and fruit ripening [46]. It also affects many biochemical and physiological functions, including photosynthesis, transpiration and enzymatic activities [47-49]. In a greenhouse microclimate, the level of light will influence both the ambient and plant leaf temperature [50]. Exposing plants to high relative humidity and continuous light reduces stomatal functions by interfering with the regulation of abscisic acid (ABA), a key plant hormone [51]. Similarly, high relative humidity and high temperature affects stomatal movement, thereby affecting plant growth, photosynthesis, transpiration and desiccation tolerance [50]. Low chilling temperatures disrupt radiation absorption by impeding the Calvin-Benson cycle of photosynthesis [52]. Temperature also plays an important role in cuticle wax morphology and chemical composition, depending on plant species [53].

\subsection{Humidity}

Humidity affects plant water status, which in turn influences all processes related to transpiration, including ion translocation, water balance and transpiration cooling [49,54]. Vapour pressure deficit (VPD) is the driving force for transpiration in plants and it changes exponentially with change in the ambient temperature [55]. Low humidity and high temperature usually increase VPD, which in turn heightens stomatal resistance and increases transpiration [45]. Similarly, low VPD is associated with reduced plant transpiration, causing dehydration, wilting and necrosis [45]. Extreme humidity affects both plant vegetative growth and fruit quality and increases the likelihood of disease [46].

\subsection{Solar Radiation (PAR Irradiance)}

Solar energy is vital for plant metabolism, growth and development [50]. In general, photosynthetically active radiation (PAR) is commonly described as the electromagnetic radiation component used by green plants for photosynthesis and is measured as PAR irradiance $\left(\mathrm{W} / \mathrm{m}^{2}\right)$ or photosynthetic photon flux density $\left(\mu \mathrm{mol} \cdot \mathrm{m}^{-2} \cdot \mathrm{s}^{-1}\right)$ [55]. PAR is more specifically defined as the electromagnetic radiation in the waveband of 400-700 nm [56]. PAR irradiance varies, depending on latitude, season, clouds, greenhouse location and transmissivity of greenhouse covering materials.

The interaction between temperature, humidity and solar radiation has been reported in many studies $[45,46,50,57-60]$. For example, temperature directly affects plant water availability, because of its ability to modulate plant water use via effects on VPD [61,62]. 


\subsection{Climate-Control Requirements for Crops in Warm Climatic Zones}

To sustainably control temperature, humidity and light intensity in warmer climates, growers must be able to adjust the microclimate of their protected farms through independent control of these three factors. Temperature inside a greenhouse structure is determined by heat exchange with the surroundings. This includes air exchange with the surroundings, soil surface, heat exchange through the walls and the roof. Similarly, humidity inside a greenhouse is determined from the ventilation and the evapotranspiration from the plants. Joudi and Farhan [22] have established the importance of soil heat exchange in estimating energy requirement for greenhouses in Mediterranean climates. They have shown the soil temperature and heat transfer as important parameters predicting the greenhouse heating and cooling load requirements. However, at the sub surface ( up to $100 \mathrm{~m}$ ) the earth surface maintains more stable temperatures that can be used for greenhouse cooling. Further details of this cooling method are provided in Section 4.4.

Table 1 provides a list of crops normally grown under controlled conditions along with their temperature and humidity control requirements. Additionally, these plants need to be exposed to enough photosynthetic flux, as also noted in Table 1.

Table 1. Optimum temperature, relative humidity $(\mathrm{RH})$ and photosynthetically active radiation, measured as photosynthetic photon flux density (PPFD), for selected greenhouse crops grown in warm climatic regions.

\begin{tabular}{|c|c|c|c|c|}
\hline Crop & Optimum Temperature $\left({ }^{\circ} \mathrm{C}\right)$ & Optimum RH (\%) & $\operatorname{PPFD}\left(\mu \mathrm{mol} \mathrm{m}{ }^{-2} \cdot \mathrm{s}^{-1}\right)$ & References \\
\hline Eggplant & $\begin{array}{l}25-28 \text { day } \\
14-16 \text { night }\end{array}$ & $65-75$ & 504 & {$[63,64]$} \\
\hline Cucumber & $25-30$ & $80-90$ & 400 & [63] \\
\hline Tomato & $\begin{array}{l}23-27 \text { day } \\
13-16 \text { night }\end{array}$ & $50-60$ & 400 & {$[38,63]$} \\
\hline Peppers & $\begin{array}{l}22-30 \text { day } \\
14-16 \text { night }\end{array}$ & $60-65$ & 504 & {$[63,64]$} \\
\hline Lettuce & $\begin{array}{l}\text { 24-28 day } \\
13-16 \text { night }\end{array}$ & $65-80$ & $260-290$ & [64-66] \\
\hline Strawberry & $\begin{array}{l}20-26 \text { day } \\
13-16 \text { night }\end{array}$ & $50-65$ & $200-400$ & [67] \\
\hline Beans & $\begin{array}{l}22-26 \text { day } \\
16-18 \text { night }\end{array}$ & $70-80$ & $336-420$ & [63] \\
\hline Peas & $\begin{array}{l}\text { 25-30 day } \\
16-18 \text { night }\end{array}$ & $70-80$ & 672 & {$[64,68]$} \\
\hline
\end{tabular}

As a result, protected cropping structures in warm climatic conditions may require a combination of technologies, depending upon the location, to maintain indoor conditions and deliver year-round output. From a commercial viewpoint, the cost of climate control needs to be economically viable for growers in these regions. For example, literature-based evidence suggests that cost of lighting in indoor farms accounts for nearly $40 \%$ of operating costs [69], which could negate any financial advantages over field farming. Upfront and operational energy costs of a protected cropping system can be reduced through (i) optimum design, (ii) energy-efficient cooling, dehumidification and lighting technologies, and (iii) incorporating renewable energy. This paper therefore provides a qualitative comparison of various technologies for climate control from the perspective of reducing energy use.

\subsection{Climate Control in Closed Greenhouses and Plant Factories}

Closed horticultural production systems have recently garnered much attention given their higher yield and resource efficiency [18,70]. However, as described above, these systems require microclimate control and illumination, which are both energy intensive [71,72]. In addition, since these structures are airtight with little natural ventilation, evapotranspiration from crops tends to increase humidity levels, thus introducing a requirement for continuous dehumidification. Managing humidity and temperature in closed greenhouses and plant factories has therefore been the focus of many studies. 
For example, Vadiee et al. [16] reviewed available technologies used in closed greenhouse systems in different geographical locations and found they all used some form of active cooling to maintain suitable microclimate conditions. The cooling technologies varied from use of ground-source thermal storage to heat pumps. However, technological systems for closed greenhouses in tropical or warm climatic conditions were not considered.

Buchholz et al. [73] developed a prototype closed greenhouse in Spain. The system, which uses a central cooling tower for cooling and dehumidification, forces hot air to rise to the roof area where it is further humidified via sprinklers. The humidified air is then directed to the greenhouse floor, while simultaneously being cooled by a ducted heat exchanger.

Harbick and Albright [70] compared energy use in greenhouses and plant factories in different climatic conditions in the United States, where greenhouses were cooled using an evaporative pad and the plant factories were cooled using a chiller. Their analysis showed that plant factories were more energy intensive than greenhouses for all the climatic conditions tested.

In a similar study, Graamans et al. [15] compared greenhouses and vertical farms (plant factories) for growing lettuce in three different climatic regions: Sweden, The Netherlands and the United Arab Emirates (UAE). Plant factories in all regions required dehumidification to maintain internal conditions along with a substantial cooling energy requirement. The energy required for air conditioning varied based on location. For instance, in hot and humid regions such as the UAE, air conditioning and dehumidification energy use (per $\mathrm{kg}$ of lettuce production) was reduced by $50 \%$ in a plant factory compared with a greenhouse [15]. However, from the overall energy-use perspective, greenhouses fared better, due to their use of natural solar radiation.

\section{Cooling Technologies for Greenhouses and Plant Factories}

Cooling technologies used for maintaining conditions inside a greenhouse can be broadly classified into two categories: active and passive (Figure 2). Active cooling technologies use a cooling energy source (e.g., chillers) and a fluid-moving device (e.g., fan or pump) to deliver cooling to the greenhouse. Passive cooling technologies use mechanisms to control the heat energy source (i.e. solar radiation) through means such as shading the roof. The suitability of these technologies varies depending upon the climatic conditions, greenhouse design and crop species. A few researchers have documented cooling technologies suitable for tropical and subtropical regions [74,75]. These reviews have mainly focused on simple and cost-effective systems, and rarely cover technologies suitable for fully closed systems (e.g., chillers) or systems such as desiccant cooling, which control the humidity of the air stream to make evaporative-cooling technologies more effective.

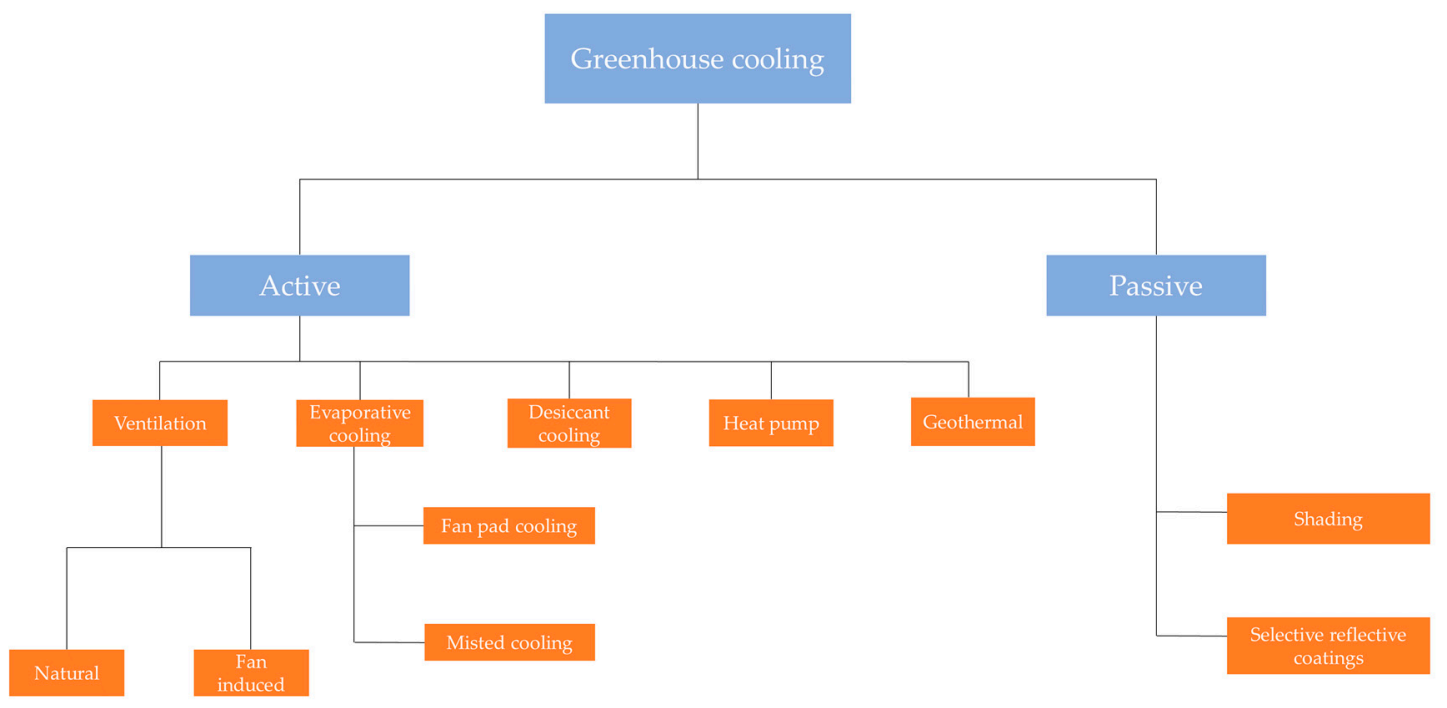

Figure 2. Active and passive cooling options for green houses and plant factories. 


\subsection{Ventilation-Based Cooling}

Natural ventilation techniques use roof and side vents of a greenhouse to replace warm, internal air with cool, external air. These methods are strictly passive, since they depend upon outside wind speed and vertical thermal gradients inside the greenhouse to move the air stream. Often these methods are also used for removing moisture from inside the greenhouse. They are economically the most attractive solution, due to their minimal infrastructure and operational energy costs, and considerable research has been dedicated to these systems.

For example, Teitel and Tanny [76] modelled the efficacy of natural ventilation, which was later validated by experiments carried out in a four-span greenhouse in Israel. The results showed that opening roof windows decreased temperature and humidity ratio over time. Kittas et al. [77] presented a model to test air exchange rate with ridge and side openings, which was also validated through experiments. Demrati et al. [78] conducted a large-scale study of the performance of natural ventilation in a multi-span greenhouse and compared the results with those of various types of greenhouse designs. Teitel et al. [79] examined the effect of continuous side openings on the ventilation rate, flow patterns, temperature, humidity and air velocity in a mono-span greenhouse. The results showed a linear increase of ventilation rate with wind speed. In addition, the temperature and humidity ratios were higher closer to the roof, while air velocity was greater near the crops. Dayan et al. [80] developed a simplified model to calculate the rate of ventilation in a greenhouse used for growing roses and obtained a good agreement between the predicted numerical values and the validation experiment. They used this model to demonstrate the influence of forced ventilation on canopy and plant temperatures. Similarly, Khaoua et al. [81] presented a two-dimensional model using computational fluid dynamics (CFD) to test the performance of vent arrangement temperature patterns and air flow. The highest ventilation rate $\left(11-26 \mathrm{~h}^{-1}\right)$ was achieved when the roof vent was placed to in the direction of wind. Impron et al. [82] presented a simplified model to predict the temperature and humidity of greenhouse in tropical lowlands of Indonesia This model included ventilation rates as an input parameter. Ganguly and Ghosh [83] developed and validated a thermal model for a naturally ventilated greenhouse with ridges and side vents in India.

Benni et al. [84] evaluated the efficacy of natural ventilation in greenhouses in hot climates. They used CFD modelling to study different vent-opening strategies on natural ventilation and suggested specific control approaches that consider wind speed and direction as the input. Espinoza et al. [85] studied the effect of ventilator configuration on the flow pattern in a Mediterranean greenhouse with obstacles to air flow (surrounding greenhouses). The ventilation rate was affected by ventilator distribution and obstruction to ventilation systems. They found that a configuration with two roof and two side vents improved overall air movement. He et al. [86] also used CFD to study the effect of back wall vents in a greenhouse during hot summer conditions in Jiangsu, China. Removing the back-wall vents reduced the maximum temperature inside the greenhouse by $5.8^{\circ} \mathrm{C}$.

Natural ventilation systems can be very effective in mild climates, and during winter in warm climates. However, they are not effective during summer in the tropical and subtropical regions where daytime temperatures are higher than that needed for maintaining greenhouse cultivation conditions. Ventilation-augmented cooling designs are used in such scenarios. For example, McCartney and Lefsrud [87] carried out field trials of a natural-ventilation-augmented cooling greenhouse in Barbados. They identified active cooling as a necessity along with ventilation for year-round growing of crops in these regions and showed that this method used much less electricity than traditional cooling methods.

In contrast to natural ventilation, fan-forced artificial ventilation uses blowers, draught and exhausts to lower or match the internal air temperature of the greenhouse to that of the ambient air [75,88]. A few researchers [89-93] have studied forced ventilation in greenhouses and established its benefits. Kittas et al. [94] presented a model for forecasting air temperature in a greenhouse with fan-induced ventilation and found that the variation between greenhouse and ambient air temperature was strongly related to incoming solar radiation and the rate of ventilation. Teitel et al. [95] compared the temperature and humidity gradient of fan-forced ventilation and fan-pad systems. Both systems 
reduced the inside temperature, but humidity inside the greenhouse was higher than the ambient humidity. Gazquez et al. [96] tested various cooling methods for growing sweet pepper and concluded that the forced-ventilation method does not control the maximum temperature as effectively as other cooling methods.

Several researchers have investigated the effect of insect screens and nets on greenhouse ventilation rates. Insect screens offer additional resistance (pressure drop) to air flow. Hence, depending upon the mesh size, they can alter air flow inside a greenhouse. For example, Soni et al. [97] identified that different porosities of screens affects the vertical temperature gradients in tropical greenhouses. Similarly, Fatnassi et al. [98] conducted mathematical modelling using CFD to evaluate the effects of insect screens on airflow, humidity and temperature. The insect mesh increased humidity and temperature when the greenhouse roof and side vents were closed. Harmanto et al. [99] established that the effects of insect nets on humidity and temperature are dependent on mesh netting size.

\subsection{Evaporative-Cooling Approaches}

Evaporative cooling is the most commonly used method for greenhouse temperature control and has been the subject of numerous studies [74,89,100-104]. The principle behind evaporative cooling is to use latent cooling provided by evaporated water to cool the air stream. This process is isenthalpic: that is, while it reduces the temperature of the air stream, humidity in the air stream increases. Evaporative-cooling systems used for protected cropping can be broadly classified into three categories based on the mechanism of water delivery and air movement: fogging (misting), fan-pad evaporative cooling and roof evaporative cooling. These systems are described below.

\subsubsection{Fogging Systems}

These designs use a fine mist (or fog) produced by spraying water inside the protected cropping structure. Fogging systems with reduced water droplet size of between 2-60 $\mu \mathrm{m}$ prevent water droplets adhering to plant foliage [105]. This method combats leaf dehydration and heat stress due to excessive temperatures [106,107] and maintains favourable leaf water status when evaporation demands are higher [106].

Montero et al. [108] used a micro-fogging cooling system in two identical multi-arch greenhouses fitted with a shading screen of $45 \%$ transmissivity, and reported a temperature decrease of $5{ }^{\circ} \mathrm{C}$ during hot days compared with an un-fogged greenhouse. Katsoulas et al. [109] investigated the effects of fogging on plant transpiration and water vapour conductance of a greenhouse-grown rose canopy. They found that crops were less stressed, but only $40 \%-45 \%$ of fogging water was found to be effective in cooling rose plants. In another study, Arbel et al. [106] carried out a study combining mechanical ventilation and fogging, which maintained an air temperature of $28{ }^{\circ} \mathrm{C}$ and a relative humidity of $80 \%$ inside the greenhouse. Ozturk [110] tested the efficacy of fogging in a multi-span greenhouse and found that it reduced greenhouse temperature by $6.6^{\circ} \mathrm{C}$ compared with the ambient temperature. Abdel-Ghany and Kozai [111] investigated evaporation behaviour in a naturally ventilated greenhouse in a hot day in Tokyo. They reported that evaporating mist absorbed sensible heat from the greenhouse. In another study, the same authors [112] computed the fraction of mist evaporated after the absorption of sensible heat from the greenhouse. Toida et al. [113] used an upward airstream fogging system that increased fog evaporation, thus cooling more efficiently while preventing fungal growth. In a similar experiment, Perdigones et al. [114] used pulse-width modulation to control fogging in a greenhouse in summer and found that this method reduces water consumption by $8 \%-15 \%$ compared to fixed fogging cycle. Zhang et al. [115] examined the effectiveness of micro-fog systems for greenhouse tomatoes during summer and found that they effectively promote biomass growth, which in turn increased yield. 


\subsubsection{Fan-Pad Evaporative Cooling}

This method consists of an evaporative-cooling pad on one side of the greenhouse and an exhaust fan/blower on the opposite sidewall. Water is circulated in the pad via pumps while hot ambient air is forced through the wet pad, cooling the air inside the greenhouse while raising relative humidity levels. This technique is effective if the air inlet humidity level is low, so that additional moisture can be added to the airstream to reduce its temperature. However, the method is not effective in humid climates.

Abdel-Wahab [116] developed a mathematical model to test the air flow rate, evaporation rate and cooling potential of a greenhouse in Saudi Arabia. A combination of fan-pad cooling and external shading greatly reduced water and energy consumption. Jain and Tiwari [101] used statistical modelling, validated through experiments, to evaluate the cooling efficacy of a greenhouse fitted with a fan-pad cooling system. They reported a temperature reduction of $4-5{ }^{\circ} \mathrm{C}$ in the greenhouse. Ganguly and Ghosh [117] developed a thermal model for a fan-pad cooled greenhouse located in India. The model showed that their system was not effective during the monsoon period. $\mathrm{Xu}$ et al. [104] studied fan-pad cooling systems in Shanghai, China and reported to a reduction in temperature of $2-3{ }^{\circ} \mathrm{C}$ below ambient conditions with relative humidity (RH) values of $80 \%$. Moreover, they found that these systems were cost effective. Various researchers e.g., [118] have studied the impact of dehumidifying humid air to improve the effectiveness of evaporative-cooling techniques. These studies are summarised in the section on humidity-control mechanisms.

\subsubsection{Roof Evaporative Cooling}

Roof evaporative cooling is achieved by circulating a thin film of water on the roof surface to reduce heat, which in turn reduces air temperature in the greenhouse. Willits and Peet [119] investigated the cooling efficacy of two greenhouses (treatment and control) fitted with woven poly-propylene sheet using an intermittent wetting method. The internal temperature was reduced by $41 \%$ in the wetted greenhouse compared with $18 \%$ for the control. In another study, Sutar and Tiwari [120] experimentally evaluated the effectiveness of roof evaporative cooling with and without shading cloth. Temperatures were reduced by $10{ }^{\circ} \mathrm{C}$ in the shaded greenhouse and by $4-5{ }^{\circ} \mathrm{C}$ in the unshaded greenhouse. Ghosal et al. [121] presented a mathematical model to test the cooling potential of roof evaporative cooling under three conditions (shading and water sprinkle, shaded and unshaded) on an even-span greenhouse in Delhi. The modelling results were experimentally validated and showed that shading and water sprinkle reduced the air temperature by $6 \%$ compared with $2 \%$ for shaded, while no reduction was observed for the unshaded greenhouse. In a similar study, Giacomelli et al. [122] reported reductions of $4{ }^{\circ} \mathrm{C}$ for a wetted shade blanket over the roof of a greenhouse, and $10^{\circ} \mathrm{C}$ for a mobile sprinkle fog nozzle. Helmy et al. [123] reported that two identical greenhouses combining roof evaporative cooling and interior evaporative cooling significantly outperform the fan-pad system. However, another study has shown that the water required for evaporative cooling is approximately $67 \%$ of the greenhouse's total water demand, and thus exceeds the water requirement for greenhouse irrigation [124]. As a result, growers in arid climates are exploring the use of sea water for evaporative cooling to meet the high-water demand. As this topic is beyond the scope of this review, it will not be explored further here.

In summary, evaporative cooling is one of the most economical active cooling methods to control temperature in protected cropping structures. However, these standalone cooling systems have limitations, due to the addition of moisture to the closed greenhouse. Hence, evaporative-cooling systems are augmented with ventilation systems to control humidity. In warm climates, evaporative cooling can reduce the cooling load inside a greenhouse and may be augmented with other active or passive cooling methods. 


\subsection{Heat-Pump Cooling Systems}

Heat-pump cooling systems are driven by electrical energy which runs a compressor that circulates a refrigerant. As a result, in warm climates, the energy used by these systems for air conditioning can be a significant component of the total energy input. Various researchers have evaluated use of heat pumps for greenhouse heating [125-130].

Chou et al. [125] used numerical modelling to study the behaviour of a heat pump for climate control and observed that it delivered the required conditions with a coefficient of performance (COP) of 1.2 to 4 . A few researchers have investigated heat pumps that use the ground as a heat sink to improve performance. For instance, Benli [129] compared the thermal performance of heating systems using ground-source heat pumps with R-22 refrigerant and concluded that vertical systems were more efficient than horizontal systems. Similarly, Esen et al. [127] compared the greenhouse heating running costs using ground-coupled heat pumps against heating methods such as coal, oil fuel, electricity, liquid petroleum gas and natural gas. The ground heat pumps outperformed all the other heating methods except natural gas. Boughanmi et al. [130] studied a geothermal heat-pump system for greenhouse cooling in Tunisia. Their experimental studies showed such systems can decrease the greenhouse temperature by $12{ }^{\circ} \mathrm{C}$ while obtaining a COP of 3.9. However, heat-pump systems for cooling in warm-climate greenhouses have not often been studied, given their higher operational costs. For example, Valino et al. [131] compared cost benefits of heat-pump based radiant cooling with fogging and ventilation for a greenhouse in Spain. They concluded that heat-pump cooling could only be justified for high-value crops, given that it costs $38 \mathrm{Euro} / \mathrm{m}^{2}$ to run heat-pump radiant cooling systems.

\subsection{Geothermal Cooling Systems}

Often referred to as shallow geothermal systems $(<100 \mathrm{~m})$, geothermal cooling uses the relatively stable, low-temperature earth surface to exchange heat and deliver cooling in warm and hot climates. For example, studies from Thailand found that the average temperatures of undisturbed soil ranged between 26 and $28^{\circ} \mathrm{C}$ at a depth of $1 \mathrm{~m}$, while daily summer temperatures can reach $50{ }^{\circ} \mathrm{C}$ inside greenhouses $[25,132]$. The differences between these temperatures suggest the viability of a ground heat exchanger (GHE) as a cooling solution for warm climate greenhouse crops (Table 1). Horizontal and vertical earth-tube heat-exchanger systems have been touted as an effective cooling method for protected cropping in tropical and subtropical regions [6]. This renewable form of energy has been extensively tested in many countries, including India [133-138], Greece [139], Turkey [20,126,140-142], China [143], Thailand [25,132,144], Kuwait [145] and Iran [146].

Ozenger et al. [142] experimented with the cooling potential of a closed-loop GHE for a greenhouse in Turkey and observed a variation in the daily COP ranging from 0.98 to 1.88. Similarly, Ghosal and Tiwari [134] tested the cooling efficiency of a GHE acquired from a depth of $1 \mathrm{~m}$ for a greenhouse and observed a reduction in temperature of 5- $6{ }^{\circ} \mathrm{C}$. Al-Ajmi et al. [145] evaluated the cooling potential of a GHE at a depth of $1.7 \mathrm{~m}$ in desert conditions in Kuwait, and found that this method reduced indoor temperatures by $2.8^{\circ} \mathrm{C}$. In Iran, Sanaye and Niroomand [146] examined the cooling and heating loads of a GHE and noted an increased COP of 3.9-5.4. In a recent study, Mongkon et al. [25] modelled the cooling performance of a GHE in two identical greenhouses and experimentally validated the model, showing predicted COPs of 2.41 and 1.9. Although the results of these studies were largely positive and demonstrate a potential for cooling glasshouses during sunny periods, the reduction in temperature and RH may not be conducive to plant growth at certain growth stages. Thus, to create a microclimate suitable for plants at different growth stages, complementary cooling methods, such as fogging, evaporative cooling and natural ventilation, could be used in conjunction with a GHE $[25,128,147]$. A few researchers have pointed out the importance of estimating the undisturbed ground temperature of areas surrounding the greenhouses, given the spatial variation of deep soil temperatures $[25,132,144]$. 


\subsection{Passive Cooling Technologies: Shading and Reflection}

Crops grown in greenhouses in tropical and subtropical regions require different forms of shading, given the high levels of solar irradiation, which can be detrimental [148]. This form of greenhouse cooling, using cloths, blinds or reflective material to reduce incoming radiation, is perhaps economically the second-best option after ventilation. Ahmed et al. [149] categorised shading methods into (i) whitewash shading, (ii) plastic net shading, and (iii) thermo-reflective shading materials. They also summarised the literature related to shading available for controlling greenhouse microclimates in hot regions and reported that it reduces greenhouse internal temperature by $5-10{ }^{\circ} \mathrm{C}$ in sunny regions. Garcia et al. [150] compared the efficacy of mobile external shading and fogging vs fixed shading for a Mediterranean greenhouse and reported that retractable shading with temperature sensors addressed shading limitations.

In recent years, photovoltaic (PV) panels on greenhouse roof surfaces have been popular in European Union countries, particularly Mediterranean countries, for generating solar energy while providing shade during summer months [151]. Driven by high public incentives, some growers covered most of the roof with PV panels without factoring in plant requirements, resulting in poor growth and productivity $[152,153]$. To test the efficacy of this method, Cossu et al. [154] investigated the light distribution of one fully covered and uncovered greenhouses located in southern Italy. The authors observed varying light distribution inside the fully covered greenhouse, with only $33 \%$ of the available light detected in comparison to a greenhouse with a transparent roof [154]. More notably, only $23 \%$ and $20 \%$ of available natural light were detected at the centre and north aspect of the covered greenhouse, respectively [154]. These findings are supported by Ahmed et al. [149] who reported that shading reduces roof transmissivity by $30 \%-50 \%$. Low levels of solar radiation decrease plant photosynthesis and respiration, which might increase susceptibility to various plant pathogens [155]. Therefore, mounting PV panels on greenhouses may generate free energy and shading, but comes at the cost of crop development and yield [154]. However, Dinesh and Pearce [156] suggested that the introduction of shade-adapted plants in these greenhouses could add economic value to the crops grown. Marrou et al. [157] also recommended the use of shade-tolerant plants in PV-mounted greenhouses. In India, Ganguly et al. [158] used a PV-covered greenhouse to grow ornamental plants with good results, showing the profitability of this method. In another study, Carlini et al. [159] found that roof-mounted PV panels provided optimal cooling and heating for greenhouse-grown tomatoes. In Japan, Cossu et al. [154] presented an algorithm to measure the global radiation within the greenhouse, thus enabling growers to choose agronomically compatible crops in PV-shaded greenhouses. Marucci et al. $[160,161]$ used transparent, flexible PV on tunnel-type greenhouses and obtained consistent shading of less than 40\%. Klaring and Krumbein [162] in Germany reported that shading greenhouses with PV reduced growth and yield of tomato plants, but without compromising fruit quality. In Greece, studies by Kavga et al. [163] and Trypanagnostopoulos et al. [164] revealed that lettuces grown in $20 \% \mathrm{PV}$-shaded greenhouses were of comparable quality to the lettuce grown in open roof greenhouses.

To circumvent some of the limitations posed by opaque PV panels, Cossu et al. [165] suggested the use of semi-transparent PV modules specifically designed for greenhouses. In another study, Cossu et al. [154] reported that semi-transparent PV with spherical microcells, which has a solar transmissivity of about $73 \%$, has the potential to replace opaque PV panels. Other studies (e.g., Kozai et al. [166]), have asserted that PV panels can be used on greenhouses without hindering solar radiation by carefully factoring in the latitude, time of year, number of panels and greenhouse orientation. Similarly, Fatnassi et al. [153] observed simply reconfiguring PV panels into a chessboard shape allowed enough solar radiation for greenhouse crops. Although many of these studies justify the application of PV in greenhouse as a shading and energy-generating system, other studies reveal a need for crop-specific shading percentages. 


\section{Humidity-Control Methods Suitable for Protected Cropping}

The humidity requirements for selected crops grown in greenhouses ranges between RH levels of $50 \%$ to $80 \%$ (Table 1). These requirements are less stringent than for buildings that aim to maintain human comfort. Humidity is the most difficult environmental factor to control in terms of greenhouse heating, cooling and related equipment [49]. The problem is exacerbated by the introduction of energy-saving mechanisms for tropical and subtropical protective cropping, including shading, insulation and reduced air exchange, which are all associated with an increase in humidity [54]. For example, Ahmed et al. [149] documented the impact of greenhouse shading on RH inside greenhouses. Shading reduced the inside temperature by up to $10^{\circ} \mathrm{C}$, which increased $\mathrm{RH}$ by up to $20 \%$. Although shading does not change the moisture content of air, it does affect its moisture-holding capacity through a reduction in temperature [149]. Similarly, Garcia et al. [150] documented the humidification benefit provided by fogging methods used for reducing greenhouse internal temperature.

Evapotranspiration from plants plays an important role in determining the air moisture content inside a greenhouse. It is dependent on plant type, total leaf area, and irradiance levels. As a result, evapotranspiration rates are higher during the daytime in greenhouses that use solar irradiance. Plants continually release moisture, which needs to be removed to maintain RH levels. As a result, most research activities have focused on removing moisture from greenhouses. An intended benefit of condensing moisture from inside a greenhouse is the release of latent heat of condensation, which can reduce the energy required for heating. However, for greenhouses that require cooling, the latent heat associated with condensation needs to be removed continually.

Humidity-control methods for greenhouses can be classified as active or passive (Figure 3). Kempkes et al. [167] evaluated three standard dehumidification strategies for greenhouses in cold climates: (i) exchange of dry, outside air through ventilation, (ii) condensation on a cold surface and (iii) using hygroscopic materials to adsorb moisture. A summary of humidity-control approaches used for various climatic zones is given in Table 2.

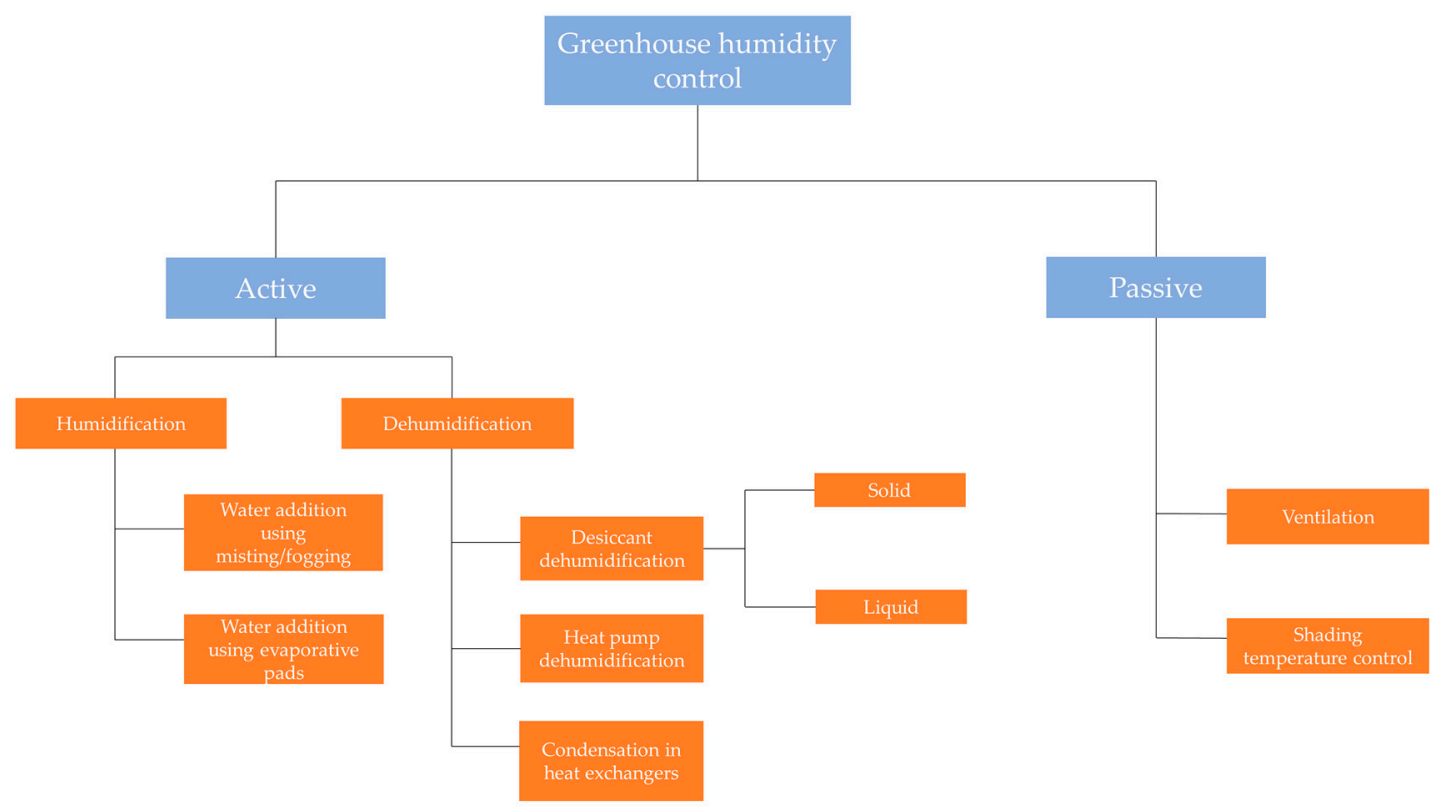

Figure 3. Active and passive humidity control methods for green houses and plant factories.

\subsection{Ventilation Based Humidity Control Methods}

The easiest and common method of dehumidification is using ventilation to replace the air inside the greenhouse with outside air. This removes the moisture produced by plant transpiration and consumes the least amount of energy compared with other dehumidification methods. However, its 
suitability depends upon factors such as ambient conditions, and the fine climatic control required for the greenhouse crop. For heating-dominated climatic regions, a heat exchanger is often used to recover some of the heat energy removed, along with ventilation methods that are used to remove moisture. Rousse et al. [168] and Campen et al. [169] established the benefits of incorporating a heat exchanger while using ventilation. Various researchers have studied dehumidification methods used for cold regions and compared ventilation-based energy use with other dehumidification approaches $[169,170]$. For instance, Han et al. [170] identified that mechanical, refrigeration-based dehumidification is effective in maintaining greenhouse control conditions throughout the year, including summer. Campen et al. [169] concluded that the use of hygroscopic materials to adsorb moisture can be effective but would have higher capital and regeneration energy costs. Piscia et al. [171] carried out coupled energy balance and CFD simulations to study the efficacy of humidity control in greenhouses and reported that ventilation was found to be useful until external $\mathrm{RH}$ reaches $85 \%$.

\subsection{Humidity-Control Methods using Heat Pump Dehumidification}

Using heat pumps to condense the moisture in air streams is common in the built environment industry. As shown in Figure 4, the heat pump operates in a thermodynamic closed cycle with a refrigerant. The refrigerant in the evaporator is available at temperatures below the dew point of the air stream. As a result, when the air stream passes over the evaporator coils, the moisture in the air condenses, resulting in recovery of water. Latent heat released during moisture condensation is used as additional sensible heat for climatic zones that require heating.

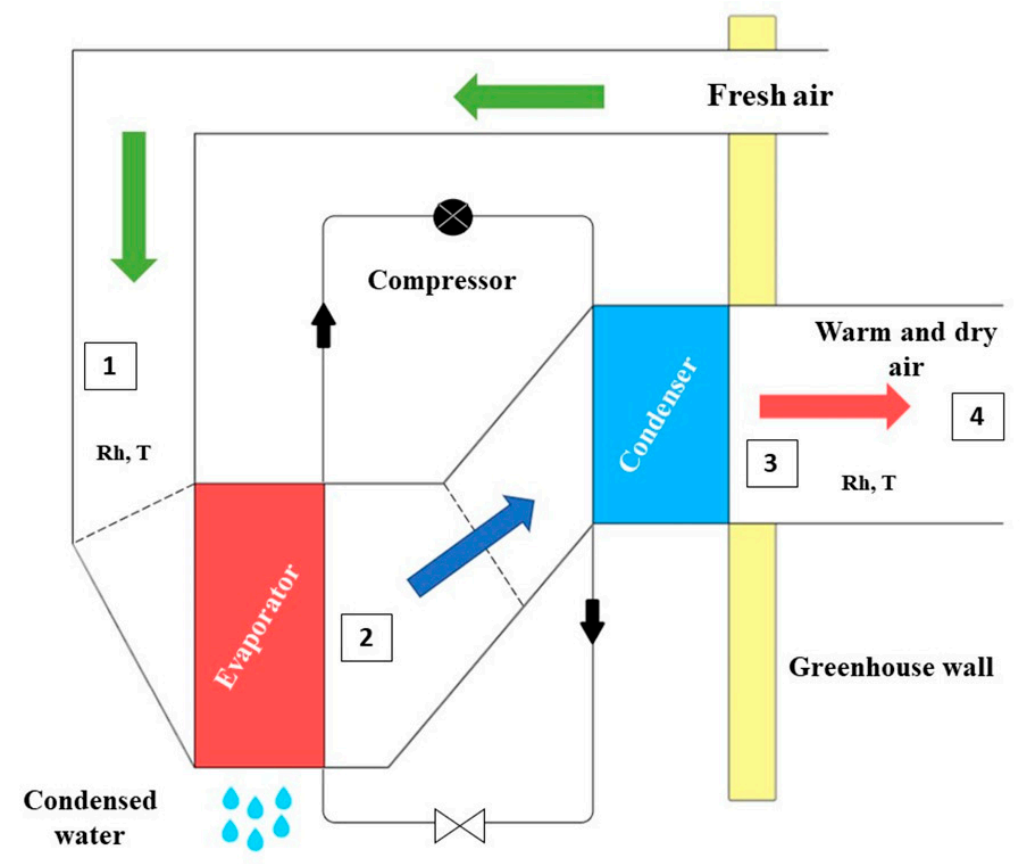

Figure 4. Schematic representation of a dehumidifying heat pump for a greenhouse (Modified from Chantoiseau et al. [172]).

Humidity-management benefits of heat pumps were reported by researchers in the 1980s $[173,174]$. The researchers concluded that heat pumps reduce moisture condensation on the interior roof of plastic greenhouses. Campen et al. [169] quantified the energy used for preventing condensation inside a greenhouse using heat pumps. Although the operating energy costs were reasonable, they asserted that the initial cost of equipment was nearly $66 \%$ of the total system installation costs. Chantoiseau et al. [172] compared heat-pump dehumidification with ventilation methods for maintaining humidity inside greenhouses. They identified that the sensible heating benefit provided by condensation-based dehumidification effectively reduced the heat needs of the greenhouse. For a heating-dominated 
greenhouse during spring and autumn, the sensible heat released from dehumidification process was enough without resorting to natural gas for heating. The authors also identified the importance of control strategies in saving energy costs.

Zapata et al. [175] evaluated the suitability of a heat-pump dehumidifier for mild weather conditions $\left(15^{\circ} \mathrm{C}, 85 \% \mathrm{RH}\right)$. The method was not effective for the tested conditions, and the author recommended further studies to improve this approach.

\subsection{Humidity-Control Methods using Adsorption Methods}

The use of desiccant materials (solid and liquid) to actively control humidity inside a greenhouse has been studied by many researchers [176-178]. Most of this research has focused on liquid desiccants, rather than solid, likely due to the ability of liquid-desiccant systems to be more easily integrated on the greenhouse roof.

To control humidity through adsorption, the process must operate continually. The adsorbed desiccant therefore needs to be regenerated using thermal energy. Given the abundance of solar radiation in many tropical and subtropical regions, solar heat can be used for this task. As shown in Figure 5, a solar-based, liquid-desiccant unit comprises a solar regenerator, a dehumidifier and a sensible cooling system. The hygroscopic liquid removes the moisture from the air stream. The liquid is regenerated using sunlight, while an indirect or direct evaporative-cooling system is used to provide sensible cooling.

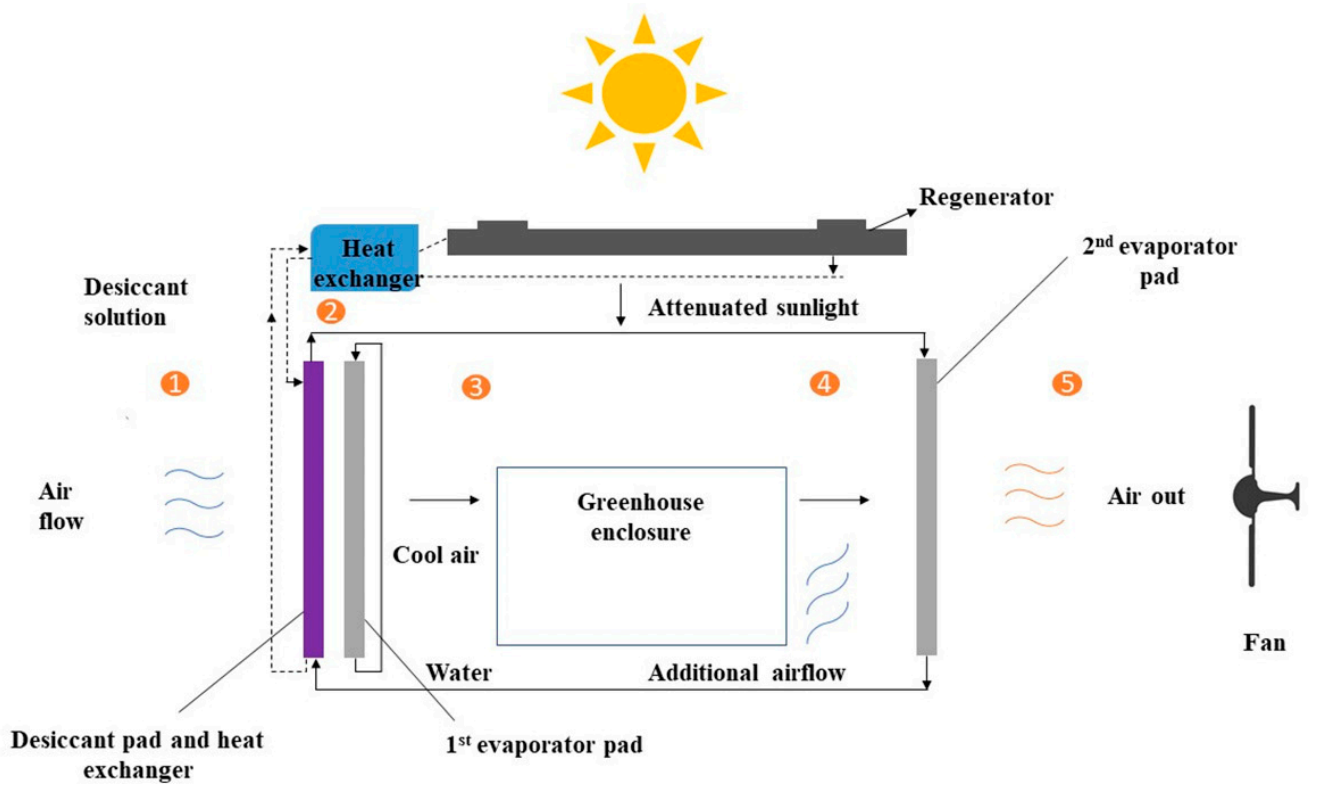

Figure 5. Schematic representation of a solar assisted liquid desiccant system with evaporative pad cooling for greenhouse crops (Modified from Davies [176]).

Davies [176] studied the suitability of liquid desiccant for cooling greenhouses in the hot and humid Gulf state of Abu Dhabi and claimed to have reduced the greenhouse summer temperature by $5{ }^{\circ} \mathrm{C}$, thus allowing the cultivation of lettuce, cucumber and tomatoes for $6-7$ months of the year. Similarly, Lychnos and Davies [177] tested the efficacy of a solar-assisted, liquid-desiccant, air-conditioning system for greenhouses in hot climates. They reported a $5.5-7.5^{\circ} \mathrm{C}$ reduction of greenhouse temperature, which in turn extended the growing season. In Saudi Arabia, Abu-Hamdeh and Almitani [178] built and evaluated a solar-assisted, liquid-desiccant cooling system with $\mathrm{Al}_{2} \mathrm{O}_{3}-\mathrm{W}$, $\mathrm{Fe}_{3} \mathrm{O}_{4}-\mathrm{W}, \mathrm{ZnO}$ and $\mathrm{Al}_{2} \mathrm{O}_{3}$ nanofluids. This system reduced the mean daily maximum temperature by $6{ }^{\circ} \mathrm{C}$. Ali et al. [179] proposed a modelling and simulation process specifically designed to counter the evapotranspiration generated by crops inside a closed greenhouse. The results obtained showed the process to be effective in removing greenhouse water vapour. In addition, simulation results for a 
greenhouse without desiccant humidity control and with desiccant dehumidification were $100 \%$ and $75 \%-85 \% \mathrm{RH}$, respectively.

Ghosh and Ganguly [65] evaluated the benefits of a solar-assisted, solid-desiccant system for a greenhouse in a subtropical climate using a silica gel wheel as the active desiccant material with an auxiliary fan-pad. This combination restricted the maximum temperature inside the greenhouse to $26{ }^{\circ} \mathrm{C}$ during the monsoon season. Sultan et al. [180] studied the suitability of various solid-desiccant materials for use in greenhouse applications. Activated-carbon-based systems were suitable for applications with $\mathrm{RH}$ requirements in the range of $40 \%-60 \%$, whereas hydrophilic silica gel was found to be suitable for applications that required $\mathrm{RH}$ values of $20 \%$.

Table 2. Summary of studies related to relative humidity $(\mathrm{RH})$ and temperature approaches used in different geographical locations with varying climatic conditions.

\begin{tabular}{|c|c|c|c|}
\hline Geographical Location & $\begin{array}{l}\text { Humidity-Control } \\
\text { Approach, Details }\end{array}$ & $\begin{array}{l}\text { Humidity \& Temperature } \\
\text { Control Range }\end{array}$ & Source \\
\hline The Netherlands & Liquid desiccant: calcium chloride & Outside humidity of $70 \%-85 \% \mathrm{RH}$ & [167] \\
\hline Canada & $\begin{array}{l}\text { Ventilation with air-to-air heat } \\
\text { exchanger for recovery of heat }\end{array}$ & Below 75\% RH inside the greenhouse & [168] \\
\hline The Netherlands & $\begin{array}{l}\text { Condensing water vapour onto } \\
\text { finned pipes }\end{array}$ & Outside air at $80 \% \mathrm{RH}$ & [169] \\
\hline France & Heat-pump dehumidification & $\begin{array}{c}\text { Avoid condensation inside the } \\
\text { greenhouse while maintaining } \\
\text { temperature at } 16^{\circ} \mathrm{C}\end{array}$ & [172] \\
\hline The Netherlands & Forced ventilation with heat exchange & Maintain RH at $80 \%$ & {$[181,182]$} \\
\hline Cold regions & $\begin{array}{c}\text { Mechanical refrigeration } \\
\text { dehumidification }\end{array}$ & Maintain $\mathrm{RH}$ at $75 \%$ & [170] \\
\hline The Netherlands & Liquid desiccant, calcium chloride & Maintain RH between 75\% and 85\% & [179] \\
\hline Spain & Heat pump dehumidifier & $\begin{array}{c}80 \text { to } 85 \% \text { RH @ ambient temperature } \\
\text { above } 15^{\circ} \mathrm{C}\end{array}$ & [175] \\
\hline Abu Dhabi & $\begin{array}{l}\text { Liquid desiccant, lithium chloride, } \\
\text { calcium chloride }\end{array}$ & Outside RH in the range of $40 \%-60 \%$ & [176] \\
\hline $\begin{array}{l}\text { Coastal cities in hot climatic } \\
\text { zones (e.g., Mumbai) }\end{array}$ & $\begin{array}{l}\text { Liquid desiccant with } \\
\text { magnesium chloride }\end{array}$ & $\begin{array}{l}\text { Various outside humidity ranges. } \\
\text { Humidity control used to improve } \\
\text { effectiveness of sensible cooling }\end{array}$ & [177] \\
\hline Saudi Arabia & Liquid desiccant, calcium chloride & $\begin{array}{l}\text { Temperature reduction by } 6{ }^{\circ} \mathrm{C} \text { in } \\
\text { humid regions due to use of desiccants } \\
\text { Maintain temperature inside the }\end{array}$ & [178] \\
\hline India (tropical, subtropical) & Solid desiccant, silica gel & $\begin{array}{l}\text { greenhouse during monsoon conditions } \\
\text { below } 27^{\circ} \mathrm{C}\end{array}$ & [118] \\
\hline India (tropical, subtropical) & Liquid desiccant, lithium chloride & $\begin{array}{l}\text { Maintain greenhouse conditions below } \\
\qquad 27^{\circ} \mathrm{C}\end{array}$ & [65] \\
\hline NA & $\begin{array}{l}\text { Solid desiccants: silica gel, activated } \\
\text { carbon powder }(\mathrm{ACP}) \text {, activated } \\
\text { carbon fibre }(\mathrm{ACF})\end{array}$ & $\begin{array}{c}60 \% \text { RH (silica gel, ACP/ACF) } \\
40 \% \text { RH (silica gel/ACF) } \\
20 \% \text { RH (silica gel) }\end{array}$ & [180] \\
\hline
\end{tabular}

\section{Concluding Remarks and Future Perspectives}

Around the globe, protected cropping has contributed significantly to food security for the last few decades and is expected to increase in future. Traditionally restricted to temperate climates, we have discussed here the economic, environmental and social benefits of protected cropping in warm climates. There is limited literature on suitable control methods for protected cropping in warm climates, and more research is needed. However, through reviewing the available literature, we have been able to summarise the cooling and humidity-control methods used in various protected cropping designs and identified that traditional crops grown in warm-climate conditions will require active climate control to improve productivity and year-round yield. We conclude that suitable climate-control solutions for specific regions will depend upon the primary objective of the design, such as reducing operating costs or increasing the accuracy of climate control.

We have also identified the following three research perspectives to help the protected cropping industry embrace suitable climate-control technology: 
(1) Establish the energy-saving potential of various climate-control approaches for warm climates. As evident from our literature review, different energy management strategies may be necessary depending upon warm-climate zone requirements. A combination of solutions may be required to address this need.

(2) Identify suitable humidity-management systems for various warm-climate conditions. Although ventilation is the simplest and preferred approach for greenhouse humidity control, in cooling-dominated climatic conditions (e.g., if the mean day time temperature is $>30^{\circ} \mathrm{C}$ ), the sensible heat addition due to ventilation would increase cooling demand. Similarly, active ventilation in tropical or subtropical climates will require controlling the humidity of fresh air before it enters the greenhouse.

(3) Primary energy-use reduction in protected cropping for warm-climate zones has received little attention. These zones have high solar availability during the day, and the highest solar radiation intensity of all climatic zones. Very few studies have investigated the benefits of using solar energy in warm-climate regions. Some studies have explored solar cooling for humidity and temperature control, but practical experience is lacking in real-life operational systems.

Supplementary Materials: The following are available online at http://www.mdpi.com/1996-1073/12/14/2737/s1. Table S1. Decline in arable land (hectares per person) from 1961 to 2015. Table S2. Comparison of potential yield between greenhouse and field grown crops.

Author Contributions: S.S. and Z.-H.C. conceived the research topic. B.R., S.S. and Z.-H.C. analysed the data and literature. B.R., S.S. and Z.-H.C. wrote the manuscript.

Funding: B.R. is supported by a Western Sydney University scholarship. S.S. is supported by CSIRO. Z.-H.C. is supported by Horticulture Innovation Australia (MT13041, VG16070), National Vegetable Protected Cropping Centre (VG17003) and Australian Research Council (DE140101143).

Conflicts of Interest: The authors declare no conflict of interest.

\section{References}

1. Lambin, E.F.; Meyfroidt, P. Global land use change, economic globalization, and the looming land scarcity. Proc. Natl. Acad. Sci. USA 2011, 108, 3465-3472. [CrossRef] [PubMed]

2. Food and Agriculture Organization. Database on arable land. 2016. Available online: https://data.worldbank. org/indicator/AG.LND.ARBL.HA.PC?view=chart (accessed on 12 February 2019).

3. Fedoroff, N. Food in a future of 10 billion. Agric. Food Secur. 2016, 4, 1-10. [CrossRef]

4. Benis, K.; Ferrao, P. Commercial farming within the urban environment-Taking stock of an evolving field in northern countries. Glob. Food Secur. 2018, 17, 30-37. [CrossRef]

5. Baker, I.; de Zeeuw, H. Urban food policies and programmes: An overview. In Cities and Agriculture: Developing Resilient Urban Food Systems, 1st ed.; de Zeeuw, H., Drechsel, P., Eds.; Routledge: Abingdon, UK, 2015; pp. 26-55.

6. Cuce, E.; Harjunowibowo, D.; Cuce, P.M. Renewable and sustainable energy saving strategies for greenhouse systems: A comprehensive review. Renew. Sustain. Energy Rev. 2016, 64, 34-59. [CrossRef]

7. Seginer, I.; Ioslovich, I. Optimal spacing and cultivation intensity for an industrialized crop production system. Agric. Syst. 1999, 62, 143-157. [CrossRef]

8. Critten, D.L.; Bailey, B.J. A review of greenhouse engineering developments during the 1990s. Agric. For. Meteorol. 1990, 112, 1-22. [CrossRef]

9. Kozai, T.; Ohyama, K.; Chun, C. Commercialized closed systems with artificial lighting for plant production. Acta Hortic. 2006, 711, 61-70. [CrossRef]

10. Kozai, T. Sustainable plant factory: Closed plant production systems with artificial light for high resource use efficiencies and quality produce. Acta Hortic. 2013, 1004, 27-40. [CrossRef]

11. Bennis, N.; Duplaix, J.; Enea, G.; Haloua, M.; Youlal, H. Greenhouse climate modelling and robust control. Comput. Electron. Agric. 2008, 61, 96-107. [CrossRef]

12. Russo, G.; Anifantis, A.S.; Verdiani, G.; Mugnozza, G.S. Environmental analysis of geothermal heat pump and LPG greenhouse heating systems. Biosyst. Eng. 2014, 127, 11-23. [CrossRef] 
13. Hadley, D. Controlled Environment Horticulture Industry Potential in NSW. UNE Business School, University of New England, 2017. Available online: https://www.une.edu.au/_data/assets/pdf_file/0010/174565/ controlled-environment-horticulture-industry-potential-hadley.pdf. (accessed on 12 February 2019).

14. Barbosa, G.; Gadelha, F.; Kublik, N.; Proctor, A.; Reichelm, L.; Weissinger, E.; Wohlleb, G.; Halden, R. Comparison of land, water, and energy requirements of lettuce grown using hydroponic vs. conventional agricultural methods. Int. J. Environ. Res. Public Health 2015, 12, 6879-6891. [CrossRef] [PubMed]

15. Graamans, L.; Baeza, E.; Dobbelstena, A.; Tsafaras, I.; Stanghellini, C. Plant factories versus greenhouses: Comparison of resource use efficiency. Agric. Syst. 2018, 160, 31-43. [CrossRef]

16. Vadiee, A.; Martin, V. Energy management in horticultural applications through the closed greenhouse concept, state of the art. Renew. Sustain. Energy Rev. 2012, 16, 5087-5100. [CrossRef]

17. Vadiee, A.; Martin, V. Energy management strategies for commercial greenhouses. Appl. Energy 2014, 114, 880-888. [CrossRef]

18. Kozai, T. Resource use efficiency of closed plant production system with artificial light: Concept, estimation and application to plant factory. Proc. Jpn. Acad. Ser. B. Phys. Biol. Sci. 2013, 89, 447-461. [CrossRef] [PubMed]

19. Qoaider, L.; Steinbrecht, D. Photovoltaic systems: A cost competitive option to supply energy to off-grid agricultural communities in arid regions. Appl. Energy 2010, 87, 427-435. [CrossRef]

20. Benli, H. Energetic performance analysis of a ground-source heat pump system with latent heat storage for a greenhouse heating. Energy Convers. Manag. 2011, 52, 581-589. [CrossRef]

21. Van Beveren, P.J.M.; Bontsema, J.; Van Straten, G.; Van Henten, E.J. Minimal heating and cooling in a modern rose greenhouse. Appl. Energy 2015, 137, 97-109. [CrossRef]

22. Joudi, K.A.; Farhan, A.A. Greenhouse heating by solar air heaters on the roof. Renew. Energy 2014, 72, 406-414. [CrossRef]

23. Bouadila, S.; Lazaar, M.; Skouri, S.; Kooli, S.; Farhat, A. Assessment of the greenhouse climate with a new packed-bed solar air heater at night in Tunisia. Renew. Sustain. Energy Rev. 2014, 35, 31-41. [CrossRef]

24. Sonneveld, P.J.; Swinkels, G.L.; Campen, A.M.; van Tujil, B.A.; Janssen, H.J.; Bot, G.P. Performance results of a solar greenhouse combining electrical and thermal energy production. Biosyst. Eng. 2010, 106, 48-57. [CrossRef]

25. Mongkon, S.; Thepa, S.; Namprakai, P.; Pratinthong, N. Cooling performance assessment of horizontal earth tube system and effect on planting in tropical greenhouse. Energy Convers. Manag. 2014, 78, $225-236$. [CrossRef]

26. Connellan, G.J. Selection of greenhouse design and technology options for high temperature regions. Acta Hortic. 2002, 578, 113-117. [CrossRef]

27. Soode, E.; Lampert, P.; Weber-Blaschke, G.; Richter, K. Carbon footprints of the horticultural products strawberries, asparagus, roses and orchids in Germany. J. Clean. Prod. 2015, 87, 168-179. [CrossRef]

28. Razo, I.; Carrizales, L.; Castro, J.; Díaz-Barriga, F.; Monroy, M. Arsenic and heavy metal pollution of soil, water and sediments in a semi-arid climate mining area in Mexico. Water Air Soil Pollut. 2004, 152, 129-152. [CrossRef]

29. Shepherd, J.M. Evidence of urban-induced precipitation variability in arid climate Regimes. J. Arid Environ. 2006, 67, 607-628. [CrossRef]

30. Kalantari, F.; Tahir, O.M.; Joni, R.A.; Fatemi, E. Opportunities and challenges in sustainability of vertical farming: A review. J. Landsc. Ecol. 2017, 2, 5-30. [CrossRef]

31. Sarkar, A.; Majumder, M. Opportunities and challenges in sustainability of vertical eco-farming: A review. J. Adv. Agric. Technol. 2015, 2, 98-105. [CrossRef]

32. Banerjee, C.; Adenaeuer, L. Up, up and away! The economics of vertical farming. J. Agric. Stud. 2014, 2, 40-60. [CrossRef]

33. Touliatos, D.; Dodd, I.C.; McAinsh, M. Vertical farming increases lettuce yield per unit area compared to conventional horizontal hydroponics. Food Energy Secur. 2016, 5, 184-189. [CrossRef]

34. Al-Kodmany, K. The vertical farm: A review of developments and implications for the vertical city. Buildings 2018, 8, 24. [CrossRef]

35. Thomaier, S.; Specht, K.; Henckel, D.; Dierich, A.; Siebert, R.; Freisinger, U.B.; Sawicka, M. Farming in and on urban buildings: Present practice and specific novelties of zero-acreage farming (ZFarming). Renew. Agric. Food Syst. 2015, 30, 43-54. [CrossRef] 
36. Dubbeling, M. Integrating urban agriculture in the urban landscape. Urban Agric. Mag. 2011, 25, 43-46.

37. Eigenbrod, C.; Gruda, N. Urban vegetable for food security in cities: A review. Agron. Sustain. Dev. 2015, 35, 483-498. [CrossRef]

38. Shamshiri, R.R.; Kalantari, F.; Ting, K.C.; Thorp, K.R.; Hameed, I.A.; Weltzien, C.; Ahmad, D.; Shad, Z.M. Advances in greenhouse automation and controlled environment agriculture: A transition to plant factories and urban agriculture. Int. J. Agric. Biol. Eng. 2018, 11, 1-22. [CrossRef]

39. De Bon, H.; Parrot, L.; Moustier, P. Sustainable urban agriculture in developing countries: A review. Agron. Sustain. Dev. 2010, 30, 21-32. [CrossRef]

40. Orsini, F.; Kahane, R.; Nono-Womdim, R.; Gianquinto, G. Urban agriculture in the developing world: A review. Agron. Sustain. Dev. 2013, 33, 695-720. [CrossRef]

41. Lovell, S.T. Multifunctional urban agriculture for sustainable land use planning in the United States. Sustainability 2010, 2, 2499-2522. [CrossRef]

42. Galhena, D.H.; Freed, R.; Maredia, K.M. Home gardens: A promising approach to enhance household food security and wellbeing. Agric. Food Secur. 2013, 2, 1-24. [CrossRef]

43. Mok, H.F.; Williamson, V.G.; Grove, J.R.; Burry, K.; Barker, S.F.; Hamilton, A.J. Strawberry fields forever? Urban agriculture in developed countries: A review. Agron. Sustain. Dev. 2014, 34, 21-43. [CrossRef]

44. Bailey, B.J. Constraints, limitations and achievements in greenhouse natural ventilation. Acta Hortic. 2000, 534, 21-30. [CrossRef]

45. Santosh, D.T.; Tiwari, K.N.; Singh, V.K.; Reddy, A.R. Microclimate control in greenhouses. Int. J. Curr. Microbiol. Appl. Sci. 2017, 6, 1730-1742.

46. Dorais, M.; Papadopoulos, A.; Gosselin, A. Greenhouse tomato fruit quality. Hortic. Rev. 2001, 26, $239-319$.

47. Bruckner, A.; Schwarz, D.; Klaring, P. Environmental factors on carotenoid content in tomato (Lycopersicon esculentum (L.) Mill.). J. Appl. Bot. Food Qual. 2006, 80, 160-164.

48. Dorais, M.; Demers, D.A.; Papadopoulos, A.P.; van Ieperen, W. Greenhouse tomato fruit cuticle cracking. Hortic. Rev. 2004, 30, 163-173.

49. Gruda, N. impact of environmental factors on product quality of greenhouse vegetables for fresh consumption. Crit. Rev. Plant Sci. 2005, 24, 227-247. [CrossRef]

50. Mortensen, L.M. The effect of photosynthetic active radiation and temperature on growth and flowering of ten flowering pot plant species. Am. J. Plant Sci. 2014, 5, 1907-1917. [CrossRef]

51. Arve, L.E.; Terfa, M.T.; Gislerød, H.R.; Olsen, J.E.; Torre, S. High relative air humidity and continuous light reduce stomata functionality by affecting the ABA regulation in rose leaves. Plant Cell Environ. 2013, 36, 382-392.

52. Potters, G.; Pasternak, T.P.; Guisez, Y.; Palme, K.J.; Jansen, M.K. Stress-induced morphogenic response; growing out of trouble. Trends Plant Sci. 2007, 12, 98-105. [CrossRef]

53. Koch, K.; Hartmann, K.D.; Schreiber, L.; Barthlott, W.; Neinhuis, C. Influences of air humidity during the cultivation of plants on wax chemical composition, morphology and leaf surface wettability. Environ. Exp. Bot. 2006, 56, 1-9. [CrossRef]

54. Bakker, J.C. The effects of day and night humidity on growth and fruit production of sweet pepper (Capsicum annuum L.). J. Hortic. Sci. 1989, 64, 41-46. [CrossRef]

55. Will, R.E.; Wilson, S.M.; Zou, C.B.; Hennessey, T.C. Increased vapour pressure deficit due to higher temperature leads to greater transpiration and faster mortality during drought for tree seedlings common to the forest-grassland ecotone. New Phytol. 2014, 200, 366-374. [CrossRef] [PubMed]

56. McCree, K.J. Test of current definitions of photosynthetically active radiation against leaf photosynthesis data. Agric. Meteorol. 1972, 10, 443-453. [CrossRef]

57. Mottus, M.; Sulev, M.; Baret, F.; Lopez-lozano, L.; Reinart, A. Photosynthetically active radiation: Measurement and Modelling. In Encyclopedia of Sustainable Science and Technology; Springer: Berlin, Germany, 2015; pp. 7970-8000.

58. Barber, J.; Anderson, B. Too much of a good thing: Light can be bad for photosynthesis. Trends Biochem. Sci. 1992, 17, 61-66. [CrossRef]

59. Darko, E.; Heydarizadeh, P.; Schoefs, B.; Sabzalian, R.M. Photosynthesis under artificial light: The shift in primary and secondary metabolism. Philos. Trans. R. Soc. B 2014, 369, 1-7. [CrossRef] [PubMed] 
60. Innes, S.H.; Arve, L.; Zimmermann, B.; Nybakken, L.; Melby, T.; Solhaug, K.; Olsena, J.E.; Torre, S. Elevated air humidity increases UV mediated leaf and DNA damage in pea (Pisum sativum) due to reduced flavonoid content and antioxidant power. Photochem. Photobiol. Sci. 2019, 18, 387-399. [CrossRef] [PubMed]

61. McDowell, N.; Pockman, W.T.; Allen, C.D.; Breshears, D.D.; Cobb, N.; Kolb, T.; Plaut, J.; Sperry, J.; West, A.; Williams, D.G.; et al. Mechanisms of plant survival and mortality during drought: Why do some plants survive while others succumb to drought? New Phytol. 2008, 178, 719-739. [CrossRef] [PubMed]

62. Williams, A.P.; Allen, C.D.; Macalady, A.K.; Griffin, D.; Woodhouse, C.A.; Meko, D.M.; Swetnam, T.W.; Rauscher, S.A.; Seager, R.; Grissino-Mayer, H.D.; et al. Temperature as a potent driver of regional forest drought stress and tree mortality. Nat. Clim. Chang. 2013, 3, 292-297. [CrossRef]

63. Sommerville, C.; Cohen, M.; Pantanella, E.; Stankus, A.; Lovatelli, A. Small-Scale Aquaponic Food Production: Integrated Fish and Plant Farming; FAO Fisheries and Aquaculture Technical Paper No. 589; Food and Agriculture Organization: Rome, Italy, 2014; pp. 1-262.

64. Tazawa, S. Effects of various radiant sources on plant growth. Jpn. Agric. Res. Q. 1999, 33, 163-176.

65. Ghosh, A.; Ganguly, A. Performance analysis of a partially closed solar regenerated desiccant assisted cooling system for greenhouse lettuce cultivation. Sol. Energy 2017, 158, 644-653. [CrossRef]

66. Kang, J.H.; Kumar, S.K.; Atulba, S.L.; Jeong, B.R.; Hwang, S.J. Light intensity and photoperiod influence the growth and development of hydroponically grown leaf lettuce in a closed-type plant factory system. Hortic. Environ. Biotechnol. 2013, 54, 501-509. [CrossRef]

67. Darrow, G.M. The Strawberry: History, Breeding and Physiology; Holt, Rhinehart and Winston: New York, NY, USA, 1966.

68. Heuvelink, E.; Dorais, M. Crop growth and yield in tomatoes. In Crop Production Science in Horticulture Series; Heuvelink, E., Ed.; CABI Publishing: Wallingford, UK, 2005; pp. 85-144.

69. McCartney, L.; Lefsrud, M.G. Protected agriculture in extreme environments: A review of controlled environment agriculture in tropical, arid, polar and urban locations. Am. Soc. Agric. Biol. Eng. 2018, 34, 455-473. [CrossRef]

70. Ghani, S.; Bakochristou, F.; ElBialy, E.; Gamaledin, S.; Rashwan, M.; Abdelhalim, A.; Ismail, S. Design challenges of agricultural greenhouses in hot and arid environments: A review. Eng. Agric. Environ. Food 2019, 12, 48-70. [CrossRef]

71. Harbick, K.; Albright, L.D. Comparison of energy consumption: Greenhouses and plant factories. In ISHS Acta Horticulturae 1134: VIII International Symposium on Light in on Horticulture 1134; International Society for Horticultural Science: Leuven, Belgium, 2016; pp. 285-292.

72. Graamans, L.; van den Dobbelsteen, A.; Meinen, E.; Stanghellini, C. Plant factories; crop transpiration and energy balance. Agric. Syst. 2017, 153, 138-147. [CrossRef]

73. Buchholz, M.; Buchholz, R.; Jochum, P.; Zaragoza, G.; Perez-Parra, J. Temperature and humidity control in the watergy greenhouse. In ISHS Acta Hortic 719: International Symposium on Greenhouse Cooling; International Society for Horticultural Science: Leuven, Belgium, 2006; pp. 401-408.

74. Sethi, V.P.; Sharma, S.K. Survey of cooling technologies for worldwide agricultural greenhouse applications. Sol. Energy 2007, 81, 1447-1459. [CrossRef]

75. Kumar, K.S.; Tiwari, K.N.; Jha, M.K. Design and technology for greenhouse cooling in tropical and subtropical regions: A review. Energy Build. 2009, 41, 1269-1275. [CrossRef]

76. Teitel, M.; Tanny, J. Natural ventilation of greenhouses: Experiments and model. Agric. For. Meteorol. 1999, 96, 59-71. [CrossRef]

77. Kittas, C.; Boulard, T.; Papadakis, G. Natural ventilation of a greenhouse with ridge and side openings: Sensitivity to temperature and wind effects. Trans. ASAE 1997, 40, 415-425. [CrossRef]

78. Demrati, H.; Boulard, T.; Bekkaoui, A.; Bourden, L. Natural ventilation and micro-climatic performance of a large-scale banana greenhouse. J. Agric. Eng. Res. 2001, 80, 261-271. [CrossRef]

79. Teitel, M.; Liran, O.; Tanny, J.; Barak, M. Wind driven ventilation of a mono-span greenhouse with a rose crop and continuous screened side vents and its effect on flow patterns and microclimate. Biosyst. Eng. 2008, 101, 111-122. [CrossRef]

80. Dayan, J.E.; Dayan, E.; Strassberg, Y.; Presnov, E. Simulation and control of ventilation rates in greenhouses. Math. Comput. Simul. 2004, 65, 3-17. [CrossRef]

81. Khaoua, S.A.; Bournet, P.E.; Migeon, C.; Boulardand, T.; Chasseriaux, G. Analysis of greenhouse ventilation efficiency based on computational fluid dynamics. Biosyst. Eng. 2006, 95, 83-98. [CrossRef] 
82. Impron, I.; Hemming, S.; Bot, G.P.A. Simple greenhouse climate model as a design tool for greenhouses in tropical lowland. Biosyst. Eng. 2007, 98, 79-89. [CrossRef]

83. Ganguly, A.; Ghosh, S. Model development and experimental validation of a floriculture greenhouse under natural ventilation. Energy Build. 2009, 41, 521-527. [CrossRef]

84. Benni, S.; Tassinari, P.; Bonora, F.; Barbaresi, A.; Torreggiani, D. Efficacy of greenhouse natural ventilation: Environmental monitoring and CFD simulations of a study case. Energy Build. 2016, 125, 276-286. [CrossRef]

85. Espinoza, K.; Lopez, A.; Valera, D.L.; Molina-Aiz, F.D.; Torres, J.A.; Pena, A. Effects of ventilator configuration on the flow pattern of a naturally ventilated three-span Mediterranean greenhouse. Biosyst. Eng. 2017, 164, 13-30. [CrossRef]

86. He, X.; Wang, J.; Guo, S.; Zhang, J.; Wei, B.; Sun, J.; Shu, S. Ventilation optimization of solar greenhouse with removable back walls based on CFD. Comput. Electron. Agric. 2018, 149, 16-25. [CrossRef]

87. McCartney, L.; Lefsrud, M.G. Field trials of the Natural Ventilation Augmented Cooling (NVAC) greenhouse. Biosyst. Eng. 2018, 174, 159-172. [CrossRef]

88. Ganguly, A.; Ghosh, S. Performance analysis of a floriculture greenhouse powered by integrated solar photovoltaic fuel cell system. J. Sol. Energy Eng. 2011, 133, 041001. [CrossRef]

89. Goodhind, G.W. Air movement in glasshouses. Shinfield 1965, 7, 61-63.

90. Carpenter, W.J.; Bark, L.D. Temperature pattern in greenhouse heating. Florists Rev. 1967, 309, 17-19.

91. Walker, J.N.; Duncan, G.A. Effectiveness of recommended greenhouse air circulation systems. Trans. ASAE 1974, 17, 371-374. [CrossRef]

92. Papadakis, G.M.; Mermier, M.; Meneses, J.F.; Boulard, T. Measurement and analysis of air exchange rates in a greenhouse with continuous roof and side openings. J. Agric. Eng. Res. 1996, 63, 219-228. [CrossRef]

93. Wang, S.; Deltour, J. An experimental ventilation function for large greenhouses based on a dynamic energy balance model. J. Agric. Eng. 1996, 5, 103-112.

94. Kittas, C.; Karamanis, M.; Katsoulas, N. Air temperature regime in a force ventilated greenhouse with rose crop. Energy Build. 2005, 37, 807-812. [CrossRef]

95. Teitel, M.; Barak, M.; Zhao, Y. Temperature and humidity gradients in fan-ventilated greenhouse under two cooling methods. Acta Hortic. 2003, 614, 469-475. [CrossRef]

96. Gazquez, J.C.; Lopez, J.C.; Baeza, E.; Saez, M.; Sanchez-Guerrero, M.C.; Medrano, E.; Lorenzo, P. Yield response of a sweet pepper crop to different methods of greenhouse cooling. Acta Hortic. ISHS. 2006, 719, 507-514. [CrossRef]

97. Soni, P.; Salokhe, V.M.; Tantau, H.J. Effect of screen mesh size on vertical temperature distribution in naturally ventilated tropical greenhouses. Biosyst. Eng. 2005, 92, 469-482. [CrossRef]

98. Fatnassi, H.; Boulard, T.; Poncet, C.; Chave, M. Optimization of greenhouse insect screening with computational fluid dynamics. Biosyst. Eng. 2006, 93, 301-312. [CrossRef]

99. Harmanto, H.J.; Salokhe, V.M. Microclimate and air exchange rates in greenhouses covered with different nets in the humid tropics. Biosyst. Eng. 2006, 94, 239-253. [CrossRef]

100. Kittas, C.; Bartzanas, T.; Jaffrin, A. Greenhouse evaporative cooling: Measurement and data analysis. Trans. ASAE 2001, 44, 683-689. [CrossRef]

101. Jain, D.; Tiwari, G.N. Modelling and optimal design of evaporative cooling system in controlled environment greenhouse. Energy Convers. Manag. 2002, 43, 2235-2250. [CrossRef]

102. Fuchs, M.; Dayan, E.; Presnov, E. Evaporative cooling of a ventilated greenhouse rose crop. Agric. For. Meteorol. 2006, 138, 203-215. [CrossRef]

103. Chen, C.; Shen, T.; Weng, Y. Simple model to study the effects of temperature on the greenhouse with shading nets. Afr. J. Biotechnol. 2011, 10, 5001-5014.

104. Xu, J.; Li, Y.; Wang, R.Z.; Liu, W.; Zhou, P. Experimental performance of evaporative cooling pad systems in greenhouses in humid subtropical climates. Appl. Energy 2015, 138, 291-301. [CrossRef]

105. Ohyama, K.; Kozai, T.; Toida, H. Greenhouse cooling with continuous generation of upward moving fog for reducing wetting of plant foliage and air temperature fluctuations: A case study. Acta Hortic. 2008, 797, 321-326. [CrossRef]

106. Arbel, A.; Barak, M.; Shklyar, A. Combination of forced ventilation and fogging systems for cooling greenhouses. Biosyst. Eng. 2003, 84, 45-55. [CrossRef] 
107. Ishii, M.; Sase, S.; Moriyama, H.; Okushima, L.; Ikeguchi, A.; Hayashi, M.; Kurata, K.; Kubota, C.; Kacira, M.; Giacomelli, G.A. Controlled environment agriculture for effective plant production systems in a semi-arid greenhouse. Jpn. Agric. Res. Q. 2016, 50, 101-113. [CrossRef]

108. Montero, J.I.; Anton, A.; Beil, A.; Franquet, C. Cooling of greenhouse with compressed air fogging nozzles. Acta Hortic. 1994, 281, 199-209. [CrossRef]

109. Katsoulas, N.; Baille, A.; Kittas, C. Effect of misting on transpiration and conductance of a green rose canopy. Agric. For. Meteorol. 2001, 106, 233-247. [CrossRef]

110. Ozturk, H.H. Evaporative cooling efficiency of fogging system for greenhouses. Turk. J. Agric. For. 2003, 27, 49-57. [CrossRef]

111. Abdel-Ghany, A.M.; Kozai, T. Dynamic modelling of the environment in a naturally ventilated, fog cooled greenhouse. Renew. Energy 2006, 31, 1521-1539. [CrossRef]

112. Abdel-Ghany, A.M.; Kozai, T. On the determination of the overall heat transmission coefficient and soil heat flux for a fog-cooled, naturally ventilated greenhouse: Analysis of radiation and convection heat transfer. Energy Convers. Manag. 2006, 47, 2612-2628. [CrossRef]

113. Toida, H.; Kozai, T.; Ohyama, K.; Handarto, H. Enhancing fog evaporation rate using an upward air stream to improve greenhouse cooling performing. Biosyst. Eng. 2006, 93, 205-211. [CrossRef]

114. Perdigones, A.; Garcia, J.L.; Romero, A.; Rodriguez, A.; Luna, L.; Raposo, C.; de la Plaza, S. Cooling strategies for greenhouses in summer: Control of fogging by pulse width modulation. Biosyst. Eng. 2008, 99, 573-586. [CrossRef]

115. Zhang, L.; Xu, P.; Mao, J.; Tang, X.; Li, Z.; Shi, J. A low cost seasonal solar soil heat storage system for greenhouse heating: Design and pilot study. Appl. Energy 2015, 156, 213-222. [CrossRef]

116. Abdel-wahab, S.K. Energy and water management in evaporative cooling systems in Saudi Arabia. Resour. Conserv. Recycl. 1994, 12, 135-146.

117. Ganguly, A.; Ghosh, S. Modelling and analysis of a fan-pad ventilated floricultural greenhouse. Energy Build. 2007, 39, 1092-1097. [CrossRef]

118. Banik, P.; Ganguly, A. Performance and economic analysis of a floricultural greenhouse with distributed fan-pad evaporative cooling coupled with solar desiccation. Sol. Energy 2017, 147, 439-447. [CrossRef]

119. Willits, D.H.; Peet, M.M. Intermittent application of water to an externally mounted greenhouse shade cloth to modify cooling performance. Trans. ASAE 2000, 43, 1247-1252. [CrossRef]

120. Sutar, R.F.; Tiwari, G.N. Analytical and numerical study of a controlled environment agricultural system for hot and dry climatic conditions. Energy Build. 1995, 23, 9-18. [CrossRef]

121. Ghosal, M.K.; Tiwari, G.N.; Srivastava, N.S.L. Modelling and experimental validation of a greenhouse with evaporative cooling by moving water film over external shade cloth. Energy Build. 2003, 35, 843-850. [CrossRef]

122. Giacomelli, G.A.; Giniger, M.S.; Krass, A.E.; Mears, D.R. Improved methods of greenhouse evaporating cooling. Acta Hortic. 1985, 174, 49-55. [CrossRef]

123. Helmy, M.A.; Eltawil, M.; Ado-shieshaa, R.R.; El-Zan, N.M. Enhancing the evaporative cooling performance of fan-pad system using alternative pad materials and water film over the greenhouse roof. Agric. Eng. Int.: CIGR J. 2013, 15, 173-187.

124. Al-Ismaili, A.M.; Jayasuriya, H. Seawater greenhouse in Oman: A sustainable technique for freshwater conservation and production. Renew. Sustain. Energy Rev. 2016, 54, 653-664. [CrossRef]

125. Chou, S.K.; Chua, K.J.; Ho, J.C.; Ooi, C.L. On the study of an energy efficient greenhouse for heating, cooling and dehumidification applications. Appl. Energy 2004, 77, 355-373. [CrossRef]

126. Ozgener, O.; Ozgener, L.; Goswami, D.Y. Performance of solar-assisted ground source heat pump system for greenhouse heating: An experimental study. Build. Environ. 2005, 40, 1040-1050. [CrossRef]

127. Esen, H.; Inalli, M.; Esen, M. Technoeconomic appraisal of a ground source heat pump system for a heating season in eastern Turkey. Energy Convers. Manag. 2006, 47, 1281-1297. [CrossRef]

128. Tong, Y.; Kozai, T.; Nishioka, N.; Ohyama, K. Reductions in energy consumption and $\mathrm{CO}_{2}$ emissions for greenhouse heated with heat pumps. Am. Soc. Agric. Biol. Eng. 2012, 3, 401-406. [CrossRef]

129. Benli, H. A performance comparison between a horizontal source and a vertical source heat pump system for a greenhouse heating in the mild climate Elaziğ, Turkey. Appl. Therm. Eng. 2013, 50, 197-206. [CrossRef] 
130. Boughanmi, H.; Lazzar, M.; Bouadila, S.; Farbat, A. Thermal performance of a conic basket heat exchanger coupled to a geothermal heat pump for greenhouse cooling under Tunisian climate. Energy Build. 2015, 1, 87-96. [CrossRef]

131. Valino, V.; Perdigones, A.; Garcia, J.L.; Luna, L. Experimental evaluation of a radiant heated floor coupled to an air to water heat pump for cooling of greenhouses. Span. J. Agric. Res. 2010, 3, 580-591. [CrossRef]

132. Arunwattana, W. An evaluation of the potential of an air conditioning system using the earth-to-air heat exchanger duct. KMUTT Res. Dev. 2008, 31, 631-642.

133. Ghosal, M.K.; Tiwari, G.N.; Das, D.K.; Pandey, K.P. Modeling and comparative thermal performance of ground air collector and earth air heat exchanger for heating of greenhouse. Energy Build. 2005, 37, 613-621. [CrossRef]

134. Ghosal, M.K.; Tiwari, G.N. Modeling and parametric studies for thermal performance of an earth to air heat exchanger integrated with a greenhouse. Energy Convers. Manag. 2006, 47, 1779-1798. [CrossRef]

135. Tiwari, G.N.; Akhtar, M.K.; Shukla, A.; Khan, M.E. Annual thermal performance of greenhouse with an earth-air heat exchanger: An experimental validation. Renew. Energy 2006, 31, 2432-2446. [CrossRef]

136. Bansal, V.; Misra, R.; Agrawal, G.D.; Mathur, J. Performance analysis of earth-pipe air heat exchanger for summer cooling. Energy Build. 2010, 42, 645-658. [CrossRef]

137. Bisoniya, T.S.; Kumar, A.; Baredar, P. Experimental and analytical studies of earth-air heat exchanger (EAHE) systems in India: A review. Renew. Sustain. Energy Rev. 2013, 19, 234-246. [CrossRef]

138. Misra, R.; Bansal, V.; Agrawal, G.D.; Mathur, J.; Aseri, T. Transient analysis-based determination of derating factor for earth air tunnel heat exchanger in summer. Energy Build. 2013, 58, 103-110. [CrossRef]

139. Santamouris, M.; Mihalakakou, G.; Balaras, C.A.; Argiriou, A.; Asimakopoulos, D.; Vallindras, M. Use of buried pipes for energy conservation in cooling of agricultural greenhouses. Sol. Energy 1995, 55, 111-124. [CrossRef]

140. Pulat, E.; Coskun, S.; Unlu, K.; Yamankaradeniz, N. Experimental study of horizontal ground source heat pump performance for mild climate in Turkey. Energy 2009, 34, 1284-1295. [CrossRef]

141. Ozgener, L.; Ozgener, O. An experimental study of the energetic performance of an underground air tunnel system for greenhouse cooling. Renew. Energy 2010, 35, 2804-2811. [CrossRef]

142. Ozgener, O.; Ozgener, L.; Goswami, D.Y. Experimental prediction of total thermal resistance of a closed loop EAHE for greenhouse cooling system. Int. Commun. Heat Mass 2011, 38, 711-716. [CrossRef]

143. Wu, M.C.; Hou, C.Y.; Jiang, C.M.; Wang, U.T.; Wang, C.U.; Chen, H.H.; Chang, H.M. A novel approach of LED light radiation improves the antioxidant activity of pea seedlings. Food Chem. 2007, 101, 1753-1758. [CrossRef]

144. Khedari, J.; Permchart, W.; Pratinthong, N.; Thepa, S.; Hirunlabh, J. Field study using the ground as a heat sink for the condensing unit of an air conditioner in Thailand. Energy 2001, 26, 797-810. [CrossRef]

145. Al-Ajmi, F.; Loveday, D.L.; Hanby, V.I. The cooling potential of earth-air heat exchangers for domestic buildings in a desert climate. Build. Environ. 2006, 41, 235-244. [CrossRef]

146. Sanaye, S.; Niroomand, B. Horizontal ground coupled heat pump: Thermal economic modeling and optimization. Energy Convers. Manag. 2010, 51, 2600-2612. [CrossRef]

147. Khan, N.; Su, Y.; Riffat, S.B. A review on wind driven ventilation techniques. Energy Build. 2008, 40, $1586-1604$. [CrossRef]

148. Castellano, S. Photovoltaic greenhouses: Evaluation of shading effect and its influence on agricultural performances. J. Agric. Eng. 2014, 45, 168-174. [CrossRef]

149. Ahmed, H.A.; Al-Faraj, A.A.; Abdel-Ghany, A.M. Shading greenhouses to improve the microclimate, energy and water saving in hot regions: A review. Sci. Hort. 2016, 201, 36-45. [CrossRef]

150. Garcia, M.L.; Medrano, E.; Guerrero, M.C.S.; Lorenzo, P. Climatic effects of two cooling systems in greenhouses in the Mediterranean area: External mobile shading and fog systems. Biosyst. Eng. 2011, 108, 133-143. [CrossRef]

151. Yano, A.; Furue, A.; Kadowaki, M.; Tanaka, T.; Hiraki, E.; Miyamoto, M.; Ishizu, F.; Noda, S. Electrical energy generated by photovoltaic modules mounted inside the roof of a north-south oriented greenhouse. Biosyst. Eng. 2009, 2, 228-238. [CrossRef]

152. Cossu, M.; Murgia, L.; Ledda, L.; Deligios, P.A.; Sirigu, A.; Chessa, F.; Pazzona, A. Solar radiation distribution inside a greenhouse with south-oriented photovoltaic roofs and effects on crop productivity. Appl. Energy 2014, 133, 89-100. [CrossRef] 
153. Fatnassi, H.; Poncet, C.; Bazzano, M.M.; Brun, R.; Bertin, N. A numerical simulation of the photovoltaic greenhouse microclimate. Sol. Energy 2015, 120, 575-584. [CrossRef]

154. Cossu, M.; Ledda, L.; Urracci, G.; Sirigu, A.; Cossu, A.; Murgia, L.; Pazzona, A.; Yano, A. An algorithm for the calculation of the light distribution in photovoltaic greenhouses. Sol. Energy 2017, 141, 38-48. [CrossRef]

155. Santamaria, P. Nitrate in vegetables: Toxicity, content, intake and EC regulation. J. Sci. Food Agric. 2006, 86, 10-17. [CrossRef]

156. Dinesh, H.; Pearce, J.M. The potential of Agrivoltaic systems. Renew. Sustain. Energy Rev. 2016, 54, $299-308$. [CrossRef]

157. Marrou, H.; Guilioni, L.; Dufour, L.; Dupraza, C.; Wery, J. Microclimate under agrivoltaic systems: Is crop growth rate affected in the partial shade of solar panels? Agric. For. Meteorol. 2013, 177, 117-132. [CrossRef]

158. Ganguly, A.; Misra, D.; Ghosh, S. Modelling and analysis of solar photovoltaic-electrolyzer fuel cell hybrid power system integrated with a floriculture greenhouse. Energy Build. 2010, 42, 2036-2043. [CrossRef]

159. Carlini, M.; Villarini, M.; Esposto, S.; Bernardi, M. Performance analysis of greenhouses with integrated photovoltaic modules. Lect. Notes Comput. Sci. 2010, 6017, 206-214.

160. Marucci, A.; Monarca, D.; Colantoni, A.; Campiglia, E.; Cappuccini, A. Analysis of the internal shading in a photovoltaic greenhouse tunnel. J. Agric. Eng. 2017, 48, 154-160. [CrossRef]

161. Marucci, A.; Zambon, I.; Colantoni, A.; Monarca, D.A. Combination of agricultural and energy purposes: Evaluation of a prototype of photovoltaic greenhouse tunnel. Renew. Sustain. Energy Rev. 2018, 82, 1178-1186. [CrossRef]

162. Klaring, H.P.; Krumbein, A. The effect of constraining the intensity of solar radiation on the photosynthesis, growth, yield and product quality of tomato. J. Agron. Crop Sci. 2013, 199, 351-359. [CrossRef]

163. Kavga, A.; Trypanagnostopoulos, G.; Zervoudakis, G.; Tripanagnostopoulos, Y. Growth and physiological characteristics of lettuce (Lactuca sativa L.) and rocket (Eruca sativa Mill.) plants cultivated under photovoltaic panels. Not. Bot. Horti Agribot. Cluj-Napoca 2018, 46, 206-212. [CrossRef]

164. Trypanagnostopoulos, G.; Kavga, A.; Souliotis, M.; Tripanagnostopoulos, Y. Greenhouse performance results for roof installed photovoltaics. Renew. Energy 2017, 111, 724-731. [CrossRef]

165. Cossu, M.; Yano, A.; Li, Z.; Onoe, M.; Nakamura, H.; Matsumoto, T.; Nakata, J. Advances on the semitransparent modules based on micro solar cells: First integration in a greenhouse system. Appl. Energy 2016, 162, 1042-1051. [CrossRef]

166. Kozai, T.; He, D.; Ohtsuka, H. Simulation of solar radiation transmission into a lean-to greenhouse with photovoltaic cells on the roof: Case study for a greenhouse with infinite longitudinal length. Environ. Control Biol. 1999, 37, 101-108. [CrossRef]

167. Kempkes, F.; Zwart, F.H.; Munoz, P.; Montero, J.I.; Baptista, F.J.; Giuffrida, F.; Gilli, C.; Stepowska, A.; Stanghellini, C. Heating and dehumidification in production greenhouses at northern latitudes: Energy use. Acta Hortic. 2017, 1164, 445-452. [CrossRef]

168. Rousse, D.R.; Martin, D.Y.; Theriault, R.; Leveillee, F.; Boily, R. Heat recovery in greenhouses: A practical solution. Appl. Therm. Eng. 2000, 20, 687-706. [CrossRef]

169. Campen, J.B.; Bot, G.P.A.; de Zwart, H.F. Dehumidification of greenhouses at northern latitudes. Biosyst. Eng. 2003, 86, 487-493. [CrossRef]

170. Han, J.; Gao, Z.; Brad, R.; Waterer, D. Comparison of greenhouse dehumidification strategies in cold regions. Appl. Eng. Agric. 2015, 31, 133-142.

171. Piscia, D.; Munoz, P.; Panades, C.; Montero, J.I. A method of coupling CFD and energy balance simulations to study humidity control in unheated greenhouses. Comput. Electron. Agric. 2015, 115, 129-141. [CrossRef]

172. Chantoiseau, E.; Migeon, C.; Chasseriaux, G.; Bournet, P.E. Heat pump dehumidifier as an efficient device to prevent condensation in horticultural greenhouses. Biosyst. Eng. 2016, 142, 27-41. [CrossRef]

173. Boulard, T.; Baille, A.; Lagier, J.; Mermier, M.; Vanderschmitt, E. Water vapour transfer in a plastic house equipped with a dehumidification heat pump. J. Agric. Eng. Res. 1989, 44, 191-204. [CrossRef]

174. Chassériaux, G. Heat pumps for reducing humidity in plastics greenhouses. Plasticulture 1987, 73, $29-40$.

175. Zapata, J.M.; Molina, J.A.; Rodriguez, F.; Lopez, J.C. Evaluation of a dehumidifier in a mild weather greenhouse. Appl. Therm. Eng. 2019, 146, 92-103. [CrossRef]

176. Davies, P.A. A solar cooling system for greenhouse food production in hot climates. Sol. Energy 2005, 79, 661-668. [CrossRef] 
177. Lychnos, G.; Davies, P.A. Modelling and experimental verification of a solar-powered liquid desiccant cooling system for greenhouse food production in hot climates. Energy 2012, 40, 116-130. [CrossRef]

178. Abu-Hamdeh, N.H.; Abu-Hamdeh, K.H. Solar liquid desiccant regeneration and nanofluids in evaporative cooling for greenhouse food production in Saudi Arabia. Sol. Energy 2016, 134, 202-210. [CrossRef]

179. Ali, A.; Ishaque, K.; Lashin, A.; Arifi, N. Modelling of a liquid desiccant dehumidification system for close type greenhouse cultivation. Energy 2017, 118, 578-589. [CrossRef]

180. Sultan, M.; Miyazaki, T.; Saha, B.B.; Koyama, S. Steady state investigation of water vapour adsorption for thermally driven adsorption-based greenhouse air conditioning system. Renew. Energy 2016, 86, 785-795. [CrossRef]

181. Campen, J.B.; Bot, P.A. Design of a low energy dehumidifying system for greenhouses. J. Agric. Eng. Res. 2001, 78, 65-73. [CrossRef]

182. Campen, J.B.; Kempkes, F.L.K.; Bot, G.P.A. Mechanically controlled moisture removal from greenhouses. Biosyst. Eng. 2009, 102, 424-432. [CrossRef]

(C) 2019 by the authors. Licensee MDPI, Basel, Switzerland. This article is an open access article distributed under the terms and conditions of the Creative Commons Attribution (CC BY) license (http://creativecommons.org/licenses/by/4.0/). 